\title{
RE-IDENTIFICAÇÃO E CARACTERIZAÇÃO GENÉTICA DA LEVEDURA IZ-987 UTILIZANDO MARCADORES MOLECULARES
}

\section{PATRICIA ANCHORENA-MATIENZO}

Dissertação apresentada à Escola Superior de Agricultura "Luiz de Queiroz", Universidade de São Paulo, para obtenção do título de Mestre em Ciências, Área de Concentração: Ciência e Tecnologia de Alimentos.

PIRACICABA

Estado de São Paulo - Brasil

Setembro - 2002 


\title{
RE-IDENTIFICAÇÃO E CARACTERIZAÇÃO GENÉTICA DA LEVEDURA IZ-987 UTILIZANDO MARCADORES MOLECULARES
}

\section{PATRICIA ANCHORENA-MATIENZO}

Engenheiro Agrônomo

Orientador: Prof. Dr. JORGE HORII

Dissertação apresentada à Escola Superior de Agricultura "Luiz de Queiroz", Universidade de São Paulo, para obtenção do título de Mestre em Ciências, Área de Concentração: Ciência e Tecnologia de Alimentos.

\author{
PIRACICABA \\ Estado de São Paulo - Brasil \\ Setembro - 2002
}




\title{
Dados Internacionais de Catalogação na Publicação (CIP) DIVISÃO DE BIBLIOTECA E DOCUMENTAÇÃO - ESALQ/USP
}

\author{
Anchorena-Matienzo, Patricia \\ Re-identific ação e c aracteriza ção genétic a da levedura IZ-987 \\ utilizando marcadores moleculares/Patricia Anchorena-Matienzo. - - \\ Piracicaba, 2002. \\ $65 \mathrm{p}$. \\ Dissertação (mestrado) - - Escola Superior de Agricultura Luiz de \\ Queiroz, 2002. \\ Bibliografia.
}

1. Marcadorgenético 2. Levedura 3. Linhagem I. Título

CDD 589.23

"Permitida a cópia total ou parcial deste documento, desde que citada a fonte - $\mathrm{O}$ autor" 
Aos meus pais, AURELIO e ESTELA, irmãos ESTELA, AIDA LUZ, FÁTIMA, e JESÚS, pelo amor, confiança e incentivo.

\section{Ofereço}

Ao meu esposo WALTER, pelo incentivo e compreensão durante todos os momentos. 


\section{AGRADECIMENTOS}

À Deus, sem o qual nada seria possível, e através dele venci mais uma etapa de minha vida.

À Escola Superior de Agricultura "Luiz de Queiroz", em especial ao Departamento de Agroindústria, Alimentos e Nutrição, pelos recursos oferecidos e oportunidade concedida para realização deste curso.

Ao Prof. Dr. Jorge Horii, pela orientação, apoio e compreensão em todos esses anos.

À Profa ${ }^{a}$ Dra. Aline A. Pizzirani-Kleiner, pela amizade, valiosas contribuições e concessão do Laboratório de Genética de Fungos Filamentosos da ESALQ/USP, onde foi possível a realização deste trabalho.

Ao Pós-doutorando Welington L. de Araújo, pela amizade, atenção, e valiosas sugestões.

À Prof ${ }^{\text {a. }}$ Dra. Sandra Ceccato-Antonini, pela amizade, apoio e por suas valiosas sugestões.

Ao Prof. Dr. Luiz C. Basso, pela colaboração na análise de cariotipagem.

À FERMENTEC S/C Ltda, Assistência Técnica em Fermentação Alcoólica, e em especial ao Prof. Dr. Antônio J. de Oliveira, pela concessão das linhagens. 
Aos funcionários do Depto. de Agroindústria, Alimentos e Nutrição, em especial à Rosemary, Vana, Gislaine, Luiz Carlos, Sylvino, Rubens, Joana e Flora, pelo carinho e amizade.

Aos amigos Fernando Gomes, Joelma Marcon, Jucy, Zezo, Anny Brites, Cecilia da Silva, Rodrigo S. Carvalho, e Antônio Sampaio, pela troca de ideias, discussões sobre temas profissionais e pessoais que muito auxiliaram na minha formação.

Às amigas Valéria Modolo, Evelise Moncaio, e Rosemary L. da Silva, por sentir tão sincera amizade. 


\section{SUMÁRIO}

LISTA DE FIGURAS................................................................... ix

LISTA DE TABELAS ............................................................. xi

RESUMO ......................................................................... Xii

SUMMARY ............................................................................ Xiv

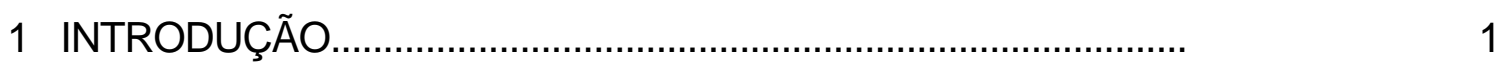

2 REVISÃO DE LITERATURA..................................................

2.1 Aspectos Gerais da Taxonomia de Leveduras............................ 4

2.2 Conteúdo de Bases Nitrogenadas............................................. 9

2.3..Caracterização Molecular de Leveduras..................................... 10

2.3.1 Uso da Eletroforese em Campo Pulsado na Identificação de Leveduras......................................................................... 10

2.3.2 Caracterização de Leveduras Baseado na Capacidade de Reassociação DNA-DNA.................................................... 15

2.3.3 Aplicação de Marcadores Moleculares..................................... 16

2.3.3.1 RAPD................................................................................

2.3.3.2 RNA Ribossomal............................................................... 20

3 MATERIAL E MÉTODOS............................................................. 22

3.1 Microrganismos Utilizados.................................................... 22

3.2 Meios de Cultura................................................................. 22

3.2.1 Meio GYP "Sabouraud" .......................................................... 23

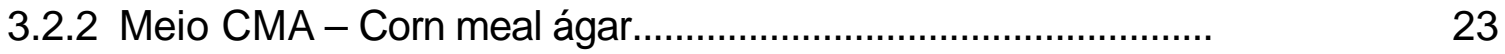

3.2.3 Meio Acetato-ágar................................................................. 23 


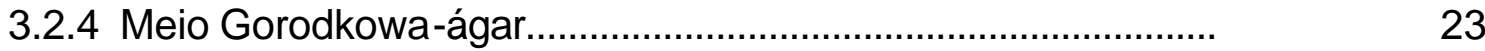

3.2.5 Meio Acetato de Potássio............................................................ 24

3.2.6 Meio Basal para Testes de Fermentação...................................... 24

3.2.7 Meio de Carbonato de Cálcio $\left(\mathrm{CaCO}_{3}\right)$ ágar................................. 24

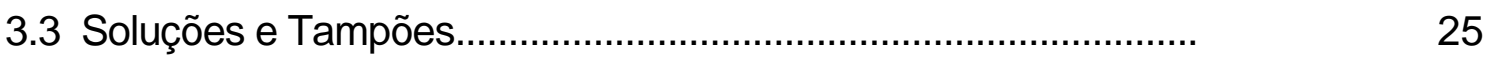

3.3.1 Solução de Brometo de Etídio................................................... 25

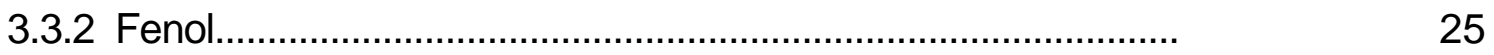

3.3.3 Clorofane ....................................................................... 25

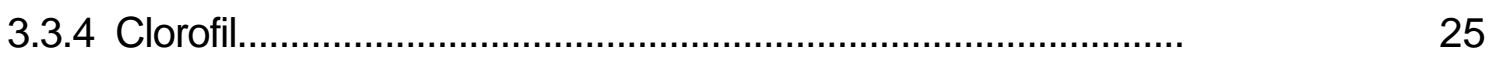

3.3.5 Ácido Etilenodiamino Tetraacético (EDTA) 0,5M

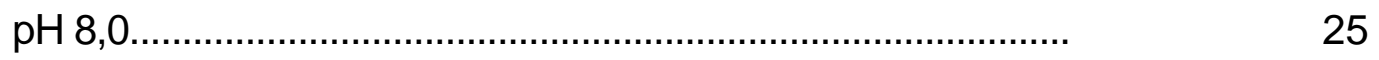

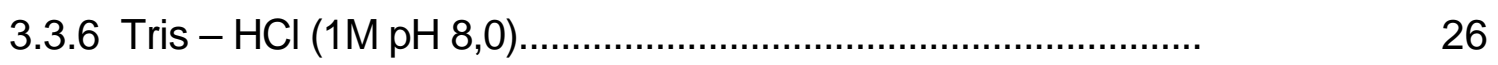

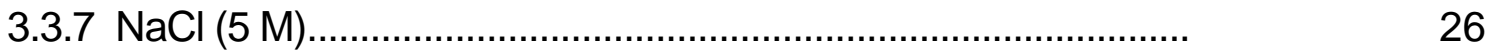

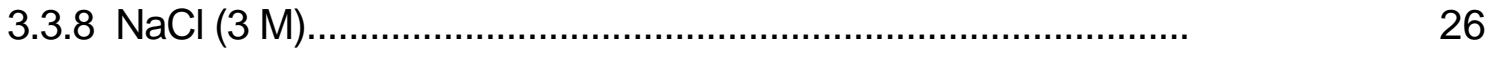

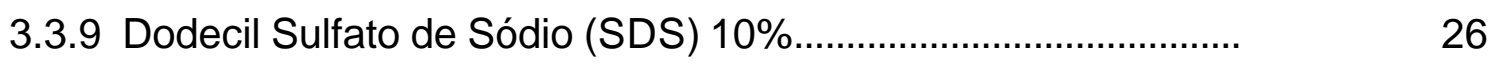

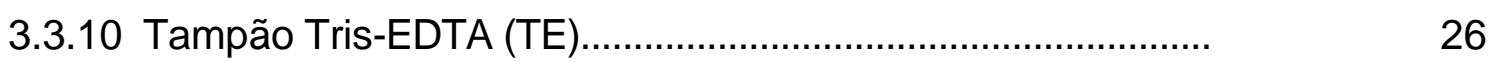

3.3.11 Tampão de Extração de DNA..................................................

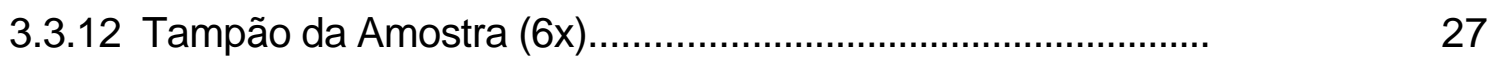

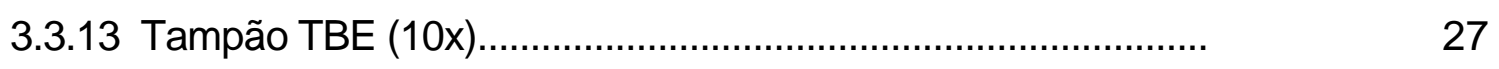

3.3.14 Gel de Agarose para Quantificação de DNA............................. 27

3.3.15 Gel de Agarose para RAPD................................................... 27

3.3.16 Gel de Agarose para PCR ....................................................... 28

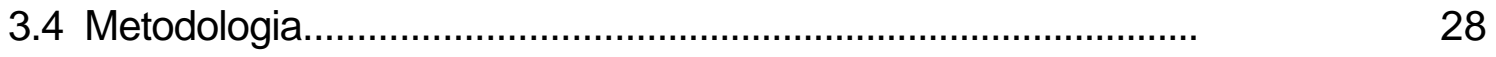

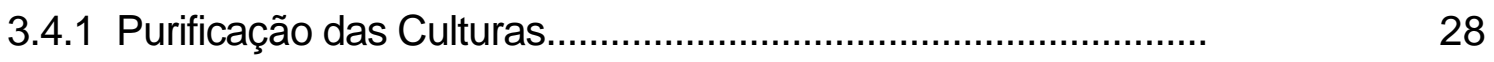

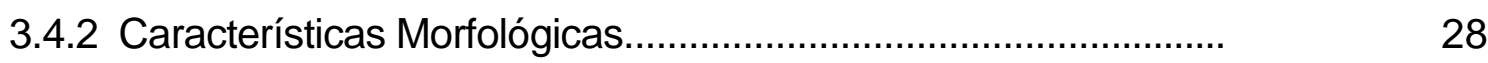

3.4.2.1 Crescimento em Meio Líquido............................................... 28

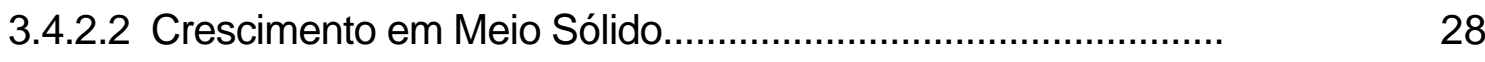

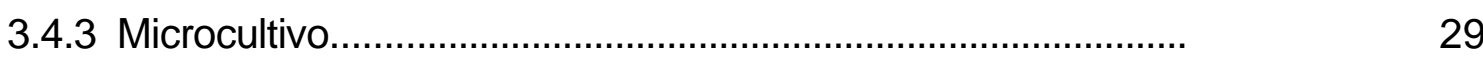

3.4.4 Características da Reprodução Sexuada.................................... 29

3.5 Características Fisiológicas e Bioquímicas..................................... 29 
3.5.1 Fermentação de Carboidratos................................................... 29

3.5.2 Assimilação de Compostos de Carbono....................................... 32

3.5.3 Assimilação dos Compostos de Nitrogênio.................................. 32

3.5.4 Crescimento àTemperatura de $37^{\circ} \mathrm{C}$.......................................... 33

3.5.5 Produção de Ácido a partir da Glicose...................................... 33

3.6 Técnicas Moleculares............................................................... 33

3.6.1 Extração de DNA das Linhagens .................................................. 33

3.6.2 Análise de Polimorfismo de DNA Amplificado ao Acaso-RAPD (Random Amplified Polimorphic DNA)..................................... 34

3.6.2.1 Método de Análise dos Dados.................................................

3.6.3 Análise de Polimorfismo Cromossomal por Eletroforese de Campo Alternado - TAFE.

3.6.4 Seqüenciamento do DNA Ribossomal (rDNA) da Levedura Z-987

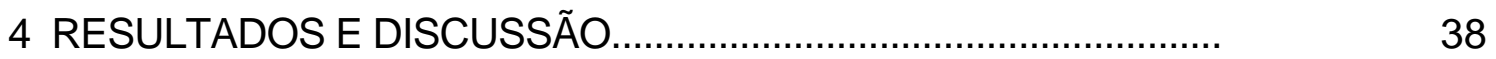

4.1 Identificação Sistemática............................................................ 38

4.1.1 Testes Morfológicos e Fisiológicos.............................................. 38

4.1.2 Testes Bioquímicos................................................................

4.2 Técnicas Moleculares................................................................

4.2.1 Polimorfismo de DNA Amplificado ao Acaso - RAPD..................

4.3 Separação de DNA Cromossômico das Leveduras........................

4.4 Seqüenciamento e Identificação da Linhagem Z-987 ..................... 51

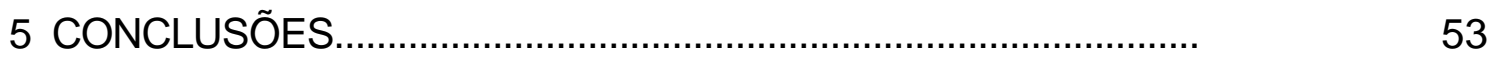

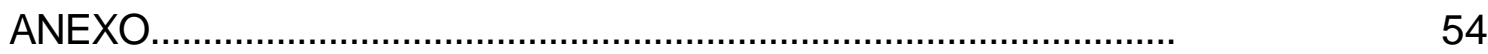

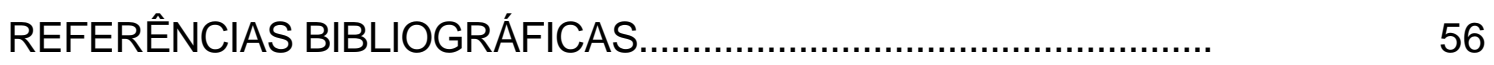


LISTA DE FIGURAS

Página

1 Teste de fermentação de carboidratos (-) ausência de crescimento e compostos não assimilados; (+) presença de crescimento.

2 Morfologia das colônias das linhagens após 6 dias de incubação em meio GYP ágar, a 30ㄷ. CR1 (Saccharomyces bayanus); IZ-987; PE-2 (S. cerevisiae); e IZ-259 (S. cerevisiae)...

3 Características micromorfológicas das linhagens apresentando a forma da célula em meio GYP líquido, incubadas a $30^{\circ} \mathrm{C}$. A) CR1 (Saccharomyces bayanus); B) IZ-987; C) PE-2 (S. cerevisiae); e D) Z-259 (S. cerevisiae); Microscopia em imersão, aumento 1000x.

4 Esporulação das células após 7 dias de incubação em meio Acetato ágar, a $30^{\circ} \mathrm{C}$. A) I-987; B) CR-1 (Saccharomyces bayanus); C) PE-2 (S. cerevisiae); e D) IZ-259 cerevisiae).....

5 Perfil de RAPD das diferentes linhagens com os primers: OPAX-17 e 2) OPB-11; M) marcador de peso molecular 100 pb Ladder (Life Technologies); A) PE-2 (Saccharomyces cerevisiae); B) IZ-259 (S. cerevisiae); C) CR-1 (S. bayanus); e D) Z-987. 
6 Dendrograma obtido a partir da matriz de similaridade genética entre as linhagens, a partir de dados obtidos pelo método RAPD, onde PE-2 (Saccharomyces cerevisiae); CR-1 (S. bayanus); IZ-259 (S. cerevisiae); e IZ987.

7 Eletroforese em campo pulsado. A) CR-1 (Saccharomyces bayanus); B) IZ-987; C) IZ-259 (S. cerevisiae); e D) PE-2 cerevisiae)

8 Gel de agarose (1,2\%) mostrando fragmento de aproximadamente $620 \mathrm{pb}$ purificado a partir da reação de PCR com os primers ITS1 e ITS4 do gene que codifica para a subunidade $18 \mathrm{~S}$ do RNA ribossômico. M) marcador de DNA $\lambda$ clivado com Hind III (Gibco BRL - Life Technologies);

A) linhagem IZ987; e B) branco. 


\section{LISTA DE TABELAS}

Página

1 Comparação entre o RFLP e o RAPD.............................................. 18

2 Características morfológicas e sexuais das linhagens de leveduras 43

3 Características de fermentação das linhagens IZ-987, PE-2, IZ-

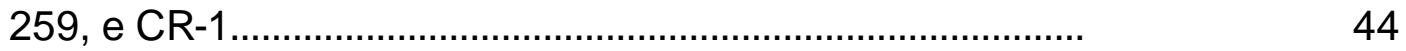

4 Características de assimilação das linhagens IZ-987, PE-2, IZ259, e CR-1 ....................................................................

5 Características bioquímicas das linhagens IZ-987, PE-2, IZ-259, e

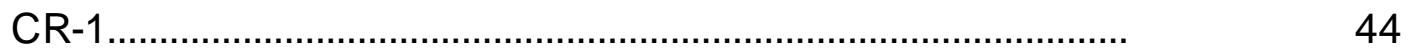

6 Assimilação das linhagens dos compostos de nitrogênio.................. $\quad 45$

7 Organização das bandas de cromossomos das leveduras de acordo com sua migração no gel...................................................

8 Análise da linhagem IZ-987 pela seqüência do 18S rDNA, e similaridade da seqüência com dados obtidos de espécies já sequenciadas e depositadas no Gene Bank................................. 


\title{
RE-IDENTIFICAÇÃO E CARACTERIZAÇÃO GENÉTICA DA LEVEDURA IZ-987 UTILIZANDO MARCADORES MOLECULARES
}

\author{
Autora: PATRICIA ANCHORENA-MATIENZO \\ Orientador: Prof. Dr. JORGE HORII
}

\section{RESUMO}

A identificação de leveduras por métodos moleculares e bioquímicos teve um grande impacto na sistemática e, devido aos resultados recentes este grupo sofreu alterações taxonômicas. A linhagem de levedura IZ-987 tem sido utilizada na fermentação de caldo de cana-de-açúcar para a obtenção de aguardente no Departamento de Agroindústria, Alimentos e Nutrição da ESALQ/USP. Esta linhagem, catalogada como Saccharomyces cerevisiae, não produz $\mathrm{H}_{2} \mathrm{~S}$ durante o processo fermentativo e apresenta a capacidade de flocular em fermentação. A análise anterior de diversidade genética por marcadores de RAPD demonstrou existir um distanciamento elevado entre esta linhagem e $S$. cerevisiae. O presente trabalho teve então por objetivo avaliar a diversidade genética entre a linhagem IZ987, e as linhagens PE-2 e IZ-259 
utilizadas como leveduras padrões pertencentes à espécie Saccharomyces cerevisiae e a levedura CR-1 como padrão de Saccharomyces bayanus, por meio das características morfológicas, fisiológicas e bioquímicas, e também por meio de marcadores de RAPD, cariotipagem e análise da seqüência das regiões ITS1 e ITS2 (Internal Transcript Subunit). Os métodos mostraram-se eficientes na diferenciação das linhagens, pois as limitações de um método puderam ser complementadas por outro. A análise morfológica mostrou que a linhagem IZ-987 não apresenta similaridade com as linhagens padrões. Os testes fisiológicos e bioquímicos apresentaram maior similaridade entre as linhagens em estudo não sendo suficiente para identificar com segurança o gênero e a espécie. As análises de diversidade genética por marcadores de RAPD e cariotipagem demonstraram que existe um distanciamento elevado entre IZ-987 e os padrões de $S$. cerevisiae. A análise da seqüência das regiões ITS1 e ITS2 (incluindo a subunidade 5,8 S do RNA ribossomal) da linhagem IZ-987, mostrou similaridade (>96\%) com a espécie Pichia anomala. 


\title{
RE- IDENTIFICATION AND GENETIC CHARACTERIZATION OF IZ-987 YEAST STRAIN USING MOLECULAR MARKERS.
}

\author{
Author: Patricia Anchorena-Matienzo \\ Adviser: Prof. Dr. Jorge Horii
}

\section{SUMMARY}

Identification of yeast by biochemical and molecular method has changed the systematic of this group. The strain IZ-987 has been used in Department of Agroindustry, Food and Nutrition, ESALQ/USP, Piracicaba/SP for alcohol production from sugarcane. This strain, which flocculates and is not able to produce $\mathrm{H}_{2} \mathrm{~S}$ during fermentation, was previously identified by classical methodology as Saccharomyces cerevisiae. In previous work, RAPD analysis showed a low level of similarity between the IZ-987 and other of S. cerevisiae strains. The aim of the present work was to examines the genetic variability among the IZ-987 strain, S. cerevisae (IZ-259 and PE-2 strains) and S. bayanus (strain CR-1) by nutritional requirements, biochemical, physiological and morphological traits as well as RAPD markers. ITS (Internal Transcript Subunit) sequencing was used in further characterization of the IZ-987 strain. The methodologies used in the present analysis were able to distinguish the strains, since that the limitation observed in one was complemented by other technique. The morphological and molecular analysis distinguished the IZ-987 strain from those of Saccharomyces genera. However, physiological and biochemical evaluation show similarity among the evaluated strains. Therefore, the results 
were not able to define the specie or genera of the IZ-987 strain. The sequencing of ITS-1, ITS-2 and 5.8S rDNA of the IZ-987 strain and analysis by BLASTn (http://www.ncbi.nlm.nih.gov) showed similarity (>96\%) of this strain with Pichia anomala. 


\section{INTRODUÇÃO}

A microbiologia teve, a partir do século XIX, um notável desenvolvimento dentro da patologia humana, veterinária e vegetal e na indústria de fermentações para produção de antibióticos, ácidos orgânicos, bebidas e álcool, entre outros. O reconhecimento da grande importância dos fungos, algas, bactérias e outros microrganismos para o homem, levou ao aprimoramento das técnicas e métodos para 0 isolamento e manutenção de novas culturas para fins de estudos de caracterização taxonômica ou ainda, para fins industriais que conduziram à organização em diversos centros de pesquisa de vastas coleções de culturas de microrganismos vivos.

De acordo com a União Internacional de Sociedades Microbiológicas (IUMS), estima-se que o número de espécies de microrganismos no planeta possa chegar a 6 milhões. Baseando-se neste dado, apenas $5 \%$ destas espécies já foram descritas.

No início, várias metodologias de classificação taxonômica foram utilizadas para a identificação das leveduras, baseadas em suas características macromorfológicas de colônia, bem como nos aspectos das células ao microscópio em função das condições do meio e testes de assimilação e fermentação em diferentes substratos, além de características fisiológicas e bioquímicas das mesmas. Embora estas forneçam valiosas informações na identificação das mesmas, apresentam a desvantagem de serem demoradas e nem sempre determinantes ou concluentes. 
Com o advento das técnicas de biologia molecular tornou-se possível a manipulação do DNA, culminando com o desenvolvimento de vários tipos de marcadores moleculares disponíveis atualmente. Os marcadores moleculares apresentam várias vantagens sobre os marcadores morfológicos por fornecerem um número ilimitado de marcas distribuídas aleatoriamente ao longo de todo o genoma e também por serem independentes dos efeitos ambientais permitindo a identificação precisa dos genótipos.

Os marcadores moleculares, como PCR (Polymerase Chain Reaction), RAPD (Random Amplified Polymorphic DNA) e cariotipagem eletroforética, apresentam procedimentos simples e rápidos de execução na sua metodologia e tem sido bastante utilizados para identificar e diferenciar linhagens de uma mesma espécie, possibilitando um rápido avanço no conhecimento da diversidade genética e contribuindo com mais um parâmetro no controle de qualidade e taxonomia de leveduras.

$\mathrm{Na}$ coleção de microrganismos do Departamento de Agroindústria, Alimentos e Nutrição, sucessora em parte do antigo Instituto Zimotécnico encontramos uma linhagem de levedura catalogada há décadas como Saccharomyces cerevisiae Z-987 e cujas características e propriedades são desejáveis nos processos fermentativos de produção de bebidas alcóolicas. Ocorre entretanto que em estudos mais recentes, Martins (1998) levantou a hipótese desta linhagem não pertencer efetivamente a espécie $S$. cerevisiae devido à dificuldade na obtenção de linhagens estáveis por diversas técnicas, incluindo a fusão de protoplastos. 
Com base nesses parâmetros, os objetivos deste trabalho foram:

- Caracterizar morfológica, fisiológica e bioquímicamente a linhagem de levedura catalogada como IZ-987.

- Comparar geneticamente a levedura IZ-987 com linhagens padrões do gênero Saccharomyces por meio de RAPD e cariotipagem eletroforética.

- Identificar a linhagem IZ-987 por meio da seqüência das regiões ITS1 e ITS2 do DNA. 


\section{REVISÃO DE LITERATURA}

\subsection{Aspectos Gerais da Taxonomia de Leveduras}

As leveduras são fungos formados por uma única célula que possuem reprodução vegetativa por brotamento ou fissão. Crescem rapidamente em meio simples, gerando alta densidade celular. Devido àfacilidade de manipulação e por apresentar altos níveis de produção de proteínas secretoras (Romanos et al., 1992), estudos genéticos neste grupo têm sido intensamente realizados. A sua distribuição é ampla, podendo, na sua maioria, serem encontradas em folhas, flores, frutos, grãos de cereais e outros substratos contendo açúcares (Carmo de Souza, 1969). Na natureza, a sua distribuição ocorre por vários vetores como ventos e correntes de água e ar, e alguns insetos. Algumas leveduras são causadoras de doenças em plantas e animais, enquanto outras são deterioradoras de alimentos, bebidas e outros materiais (Phaff \& Starmer, 1969).

As primeiras observações microscópicas de leveduras foram feitas por Antonie van Leeuwenhoek em 1680, analisando a fermentação de cerveja. Cagniard de la Tour, Kiitzing e Schwann em 1826, demonstraram que as leveduras de cerveja e vinho apresentavam capacidade de reprodução por gemulação.

Mais tarde, Pasteur demonstrou que as leveduras possuiam habilidade respiratória e fermentativa, e introduziu métodos de obtenção de culturas puras. Assim mesmo, Emil Christian Hansen descreveu características 
morfológicas e fisiológicas das leveduras, estabelecendo o primeiro sistema de identificação em 1896, que abordou a caracterização de um grande número de espécies, muitas das quais reconhecidas até hoje. Nestes esquemas foram discutidos alguns aspectos fisiológicos importantes de classificação, como a habilidade de leveduras em fermentar glicose, galactose, sacarose, maltose, lactose e rafinose e alguns compostos nitrogenados, tais como sulfato de amônia, asparagina, uréia, peptona e nitrato (Phaff et al., 1978).

Carmo de Souza (1969) estudou que as leveduras dependem de fontes de carbono orgânico para seu crescimento e obtenção de energia, sendo os carboidratos os nutrientes de maior importância; alguns açúcares simples como a glicose, frutose e manose são assimilados por todas as espécies estudadas enquanto que alguns oligosacarídeos, polissacarídeos, álcoois primários, polióis, ácidos orgânicos, pentoses, tetroses, hidrocarbonetos e lipídeos são utilizados seletivamente por algumas espécies. O crescimento a temperaturas elevadas em meios com altos teores de açúcares ou cloreto de sódio, o requerimento de vitaminas, a susceptibilidade a certas drogas como a ciclohexamida e a produção de determinados metabólitos são critérios também utilizados na descrição e classificação de leveduras, e são importantes uma vez que auxiliam no agrupamento das linhagens de acordo com o habitat da levedura (Phaff, 1990).

Em 1952, Lodder \& Kreger-van Rij escreveram a mais extensa publicação sobre taxonomia de leveduras, revisada por Lodder (1971), Barnett et al. (1983), Kreger-van Rij (1984b) e Barnett et al. (1990). Na tentativa de simplificar os processos de identificação de leveduras foi editado um programa para computadores de acordo com as publicações de Barnett et al. (1983 e 1990), utilizando-se predominantemente, testes fisiológicos. Este programa permite fazer uma seleção de espécies com resultados semelhantes æ̀̀ espécies não conhecidas, e pode ser utilizado para espécies com características individuais ou para um número de espécies com características em comum. 
As leveduras são tradicionalmente caracterizadas, classificadas e identificadas através de características morfológicas e fisiológicas. Para a identificação específica, estudos bioquímicos e de exigências nutricionais são mais relevantes que traços morfológicos e sexuais, os quais são importantes na determinação genérica. Diferenças na fermentação e assimilação de compostos de carbono são critérios importantes na taxonomia e identificação de leveduras, pois estes microrganismos apresentam uma variação na habilidade de fermentação de açúcares. Alguns grupos apresentam fermentação vigorosa da glicose como Kluyveromyces, Saccharomyces, Torulaspora e Zygosaccharomyces, enquanto outros, como Lipomyces e Sterigmatomyces são estritamente não-fermentativos. Normalmente apresentam habilidade de assimilar amônia, mas nem sempre de assimilar nitratos, nitritos, aminas ou alguns aminoácidos. Muitos gêneros como Saccharomyces, Kluyveromyces, Pichia e Debaryomyces, são caracterizados pela incapacidade de utilizar o nitrato, enquanto que nos gêneros Hansenula, Pachysolen, Citeromyces e Wickerhamiella, todas as espécies utilizam o nitrato. Entre as leveduras imperfeitas podem ocorrer linhagens nitrato-positivo e nitrato-negativo, como nos gêneros Candida e Trichosporon (Walt \& Yarrow, 1984).

Embora muitos estudos sobre a caracterização de leveduras já tenham sido elaborados, uma classificação perfeita é ainda um grande objetivo a ser alcançado. A classificação ideal deve estar baseada na filogenia destes microrganismos. Esta interação classificação-filogenia é de grande importância, pois permite predizer similaridades genéticas entre os microrganismos, fornecendo informações necessárias para a descoberta e avaliação de parentescos entre linhagens e espécies, resultando em maior compreensão da evolução das leveduras (Kreger-van Rij, 1980; Kurtzman, 1988).

Segundo Kreger-van Rij (1987) as metodologias aplicadas àidentificação de leveduras envolvem procedimentos como 0 isolamento do ambiente, 
determinação de propriedades morfológicas e fisiológicas, descrição e comparação com microrganismos padrão e ocasionalmente, avaliação de propriedades tecnológicas. O conjunto de dados obtidos, obedecendo rigorosamente a protocolos padronizados, resulta na identificação e posicionamento taxonômico da levedura.

Taylor \& Marsh (1984) estudaram o emprego de componentes inibitórios ou nutrientes específicos aos meios de cultura que permitem o crescimento e desenvolvimento de apenas alguns grupos de leveduras. Neste aspecto, os meios Schwarz Differential Medium (SDM), Cristal Violeta ágar, Lin ágar e Lin ágar modificado permitem que espécies selvagens do gênero Saccharomyces sejam detectadas. Para diferenciar leveduras não-Saccharomyces, o meio Lisina ágar é amplamente usado em processos fermentativos. Esse meio contém essencialmente Lisina como única fonte de nitrogênio, o que impede o crescimento da maioria das espécies de Saccharomyces que não se desenvolvem em meios com cristal violeta.

Ceccato et al. (2000) verificaram a eficiência de meios diferenciais $\left(W_{\mathrm{LN}}\right.$, $W_{\mathrm{LD}}$, Lisina ágar e $\mathrm{L}_{\mathrm{wr}}$ ) no isolamento de leveduras do vinho de dornas de fermentação, assim como procedem a identificação dos isolados de acordo com a metodologia clássica, onde foi observado a diferenciação morfológica das colônias. As leveduras foram identificadas de acordo com a metodologia recomendada por Kreger-van Rij (1984b), que consiste na classificação vegetativa da célula, reprodução sexuada e testes fisiológicos e bioquímicos.

Os testes fisiológicos têm sido utilizados como um importante marcador, auxiliando na definição dos grupos delimitados pelos métodos moleculares. Por estes estudos foi estabelecida a sua importância para a taxonomia, demonstrando a eficiência do método, principalmente para a diferenciação interespecífica e similaridade intraespecífica. 
Atualmente tem sido descritas aproximadamente 550 espécies de leveduras, sendo que a maior parte dessas descrições está baseada em poucos isolados (Barnett et al., 1990). As leveduras são classificadas como fungos pertencentes à divisão Eumycota (Eumycetes), classes Ascomycetes, Basidiomycetes e Deuteromycetes. Leveduras ascomicéticas e basidiomicéticas produzem esporos e apresentam um ciclo sexual já conhecido. As leveduras deuteromicéticas, também conhecidas como leveduras imperfeitas, não possuem ciclo sexual conhecido ou descrito, apresentando características morfológicas semelhantes às leveduras ascomicéticas ou basidiomicéticas (Kreger-van Rij, 1984a; Kurtzman, 1988; Phaff, 1990).

Rosini et al. (1982) estudaram a classificação de cinco espécies do gênero Saccharomyces associadas à indústria vinícola através da composição de base do DNA e reassociação DNA-DNA.

Segundo Thornton \& Bunker (1989) as culturas puras de leveduras de vinho são taxonomicamente classificadas como pertencentes à espécie Saccharomyces cerevisiae, mas elas diferem significativamente nas suas propriedades de fabricação do vinho. Estas leveduras podem apresentar algumas características que afetam a fabricação do vinho, que incluem produção de ácido sulfídrico, floculação, resistência ao cobre, produção de aromas fenólicos e capacidade "Killer".

Nos últimos anos, técnicas de identificação de leveduras foram aprimoradas e novos gêneros e espécies foram descritos ou rearranjados. Leveduras e fungos tipo-leveduras (yeast-like-fungi) associados à substratos naturais, pertencentes aos gêneros Pichia e Hansenula foram estudados e rearranjados em outros gêneros e sub-gêneros, caracterizados pela heterogeneidade e confirmados por análises taxonômicas mais profundas. Assim, o gênero Pichia foi dividido em dois sub-gêneros: Pichia e Hansenula. Sugeriuse que linhagens com esporos em forma de chapéu pertencentes aos gêneros 
Pichia e Hansenula fossem consideradas do gênero Pichia. As espécies de Pichia com esporos em forma de saturno foram excluídas deste gênero e incluídas no gênero Williopsis. Foram excluídas também espécies de Pichia com esporos globosos, que foram colocadas no gênero Zygopichia. As espécies com esporos em forma de chapéu e formadoras de micélio verdadeiro foram colocadas no gênero Hyphopichia (Kocková-Kratochvílová et al., 1989).

Sorrells et al. (1993) realizaram um estudo baseado na pressuposição de que similaridade morfológica indica similaridade genética. $O$ forte efeito dos genes determinantes de marcadores morfológicos podem afetar a análise genética de grande número de caracteres de importância. Por outro lado, os marcadores morfológicos não têm sido utilizados intensamente para o mapeamento dos caracteres devido àsuas limitações.

\subsection{Conteúdo de Bases Nitrogenadas}

Nakase \& Komagata (1971) utilizaram a composição de base do DNA (conteúdo GC) de 84 culturas de Saccharomyces e leveduras para esclarecer relações taxonômicas e filogenéticas entre estes microrganismos.

O uso do conteúdo de guanina e citosina $(G+C)$ foi difundido para a determinação da seqüência complementar do DNA nuclear usando um dos diversos métodos de reassociação do DNA. Isto, muitas vezes, conduz àrejeição de espécies, as quais têm sido separadas por taxonomia convencional com base nos poucos caracteres fenotípicos (Vaughan-Martini et al., 1993).

A determinação da composição de bases de DNA, estabelecida pela porcentagem de $\mathrm{G}+\mathrm{C}$, tem aberto novos caminhos para uma melhor separação das espécies de leveduras. Kurtzman \& Phaff (1969), em uma revisão da composição de DNA de leveduras, mencionaram que leveduras ascomicéticas apresentaram um conteúdo de $\mathrm{G}+\mathrm{C}$ abaixo de $50 \%$ (entre $27-50 \%$ ), enquanto que as basidiomicéticas apresentaram valores superiores (entre $50-70 \%$ ), embora 
algumas espécies de ascomicetos tenham sido encontrados com valores de $\mathrm{G}+\mathrm{C}$ pouco acima de 50\%. As leveduras ascomicéticas são freqüêntemente fermentativas e não possuem as enzimas urease e DNAse. As leveduras basidiomicéticas, com raras exceções, são estritamente oxidativas, apresentam urease e DNAse, e quanto reagem com o sal diazonium blue $B$ (DBB) revelam uma coloração vermelho-violeta.

\subsection{Caracterização Molecular de Leveduras}

\subsubsection{Uso da Eletroforese em Campo Pulsado na Identificação de Leveduras}

A partir da década de 60 a análise de variantes de uma população deixou de ser restrita à caracteres morfológicos, pois surgiram os marcadores moleculares.

Ferreira \& Grattapaglia (1998) definiram marcador molecular como todo e qualquer fenótipo molecular oriundo de um gene expresso, como no caso das isoenzimas, ou de um segmento específico de DNA (correspondentes a regiões expressas ou não no genoma). Portanto, pode-se dizer que atualmente a detecção de variabilidade genética pode ser feita através de diferentes níveis de observações

A aplicação de métodos moleculares poderá auxiliar na definição de alguns grupos taxonômicos. De acordo com Hoog (1997), os métodos moleculares são ferramentas úteis no esclarecimento mais preciso da posição das leveduras dentro do reino Fungi.

Kersters \& De Ley (1975) usaram com sucesso a eletroforese em géis de poliacrilamida de proteínas celulares para a classificação e identificação de microrganismos. 
A primeira técnica empregada foi designada eletroforese em campo pulsado (PFGE - Pulsed Field Gel Eletrophoresis), a qual utiliza dois campos elétricos pulsados, um homogêneo e um não homogêneo. Utilizando esta técnica, Schwartz \& Cantor (1984) separaram bandas cromossômicas de S. cerevisiae com peso molecular superior a $700 \mathrm{~Kb}$.

O sistema CHEF (Countour-Clamped Homogeneous Electric Fields), descrito por Chu et al. (1986) é constituído de 24 eletrodos que oferecem ângulos de reorientação de $60^{\circ}$ ou $120^{\circ}$. Tal técnica fundamenta-se nos princípios da eletrostática para calcular as voltagens necessárias para gerar campos elétricos homogêneos, utilizando múltiplos eletrodos dispostos ao longo de um contorno hexagonal que unidos tem seus potenciais elétricos pré-determinados. Uma vantagem dessa técnica é que o padrão de separação das bandas independe da posição do gel, de modo que as bandas de DNA ficam em ordem linear; a outra vantagem é que a distribuição hexagonal permite separação de moléculas de DNA de até $2.000 \mathrm{~Kb}$ (Pizzirani-Kleiner \& Azevedo, 1989). Este sistema tem sido usado com sucesso para separar moléculas de DNA de alto peso molecular quando alguns parâmetros são modificados, tais como maior tempo de corrida, maior tempo de pulso e menor voltagem (Vollrath \& Davis, 1987).

Carle \& Olson (1984 e 1986) utilizaram o método de separação de cromossomos para identificação de linhagens de leveduras. Foi utilizado OFAGE (Orthogonal Field Alternation Gel Electrophoresis) para estabelecer um padrão de bandas para Saccharomyces cerevisiae e permitir a identificação de linhagens desta levedura. Foram detectadas 12 bandas sendo que 9 bandas corresponderam a um cromossomo cada e 3 bandas continham 2 cromossomos em cada totalizando os 15 cromossomos da espécie.

Com o método OFAGE conseguiram estabelecer padrões de bandas de 22 ascomicetos e 4 basidiomicetos. Tal estudo permitiu verificar que o padrão apresentado pelas linhagens Saccharomyces cerevisiae é o único que apresenta 
no mínimo 4 bandas abaixo de $500 \mathrm{~Kb}$, em contrario, com as outras 25 linhagens que apresentavam a maioria de suas bandas acima de $1000 \mathrm{~Kb}$ (Jonge et al., 1986).

Degré et al. (1989) demostraram as vantagens e desvantagens de seis métodos para a identificação de leveduras de vinho. Os métodos utilizados foram: fermentação e assimilação de açúcares, eletroforese de proteínas, toxina Killer, análise de ácidos graxos voláteis, separação de cromossomos RGE e DNA Fingerprinting. Os resultados permitiram concluir que somente um método não é capaz de diferenciar claramente as linhagens de Saccharomyces spp.

Carle \& Olson (1984) efetuaram algumas modificações principalmente com relação a disposição dos eletrodos na cuba. Esta alteração resultou na segunda técnica, OFAGE a qual utiliza dois campos elétricos não homogêneos. Como os campos elétricos não eram uniformes e o ângulo entre eles variava através do gel, uma melhor resolução foi observada, quando comparada com o PFGE ( Pulsed Field Gel Electrophoresis), pois o padrão de migração era mais linear, o que permitia também colocar mais amostras no gel. Utilizando este novo sistema, foram feitos os "cariótipos eletroforéticos" de Saccharomyces cerevisiae.

Um terceiro sistema surgiu quando Gardiner et al. (1986) modificaram o sistema anterior (OFAGE) orientando o campo elétrico transversalmente no gel TAFE. O ângulo entre os campos elétricos variava da superfície superior a superfície inferior do gel. Através deste sistema foram produzidos os "cariótipos eletroforéticos" de Saccharomyces cerevisiae (Gardiner \& Partesson, 1988), e de Schizosaccharomyces pombe (Stewart et al., 1988).

Carle et al. (1986) desenvolveram um quarto sistema no qual os campos elétricos designados FIGE (Field Inversion Gel Electrophoresis) formavam um ângulo de $180^{\circ}$ entre si, podendo separar grandes moléculas de DNA com a simples inversão periódica de um campo elétrico uniforme em uma direção. Para que a separação ocorresse, o tempo de pulso para avançar tinha que ser superior 
ao tempo de pulso para reverter. A proporção utilizada normalmente foi 3:1 segundos. Uma observação interessante foi que dependendo das condições da corrida, grandes fragmentos de DNA não migraram necessariamente em ordem de tamanho das moléculas (Lalande et al., 1987).

McCluskey et al. (1990) utilizaram o método de comparação de cromossomos por eletroforese de campo pulsado PFGE que estabeleceram cariótipos bastante precisos de Saccharomyces cerevisiae, Ustilago hordeii, Tilletia caries e $T$. controversa, utilizando células intactas para execução do método.

Grandes progressos na taxonomia de leveduras vem ocorrendo em função do emprego de técnicas moleculares que fornecem informações essenciais sobre a composição química da parede celular e seqüências de ácidos nucléicos e proteínas (Meyer, 1991), o que tem resultado na descoberta de novas espécies e rearranjos de gêneros e espécies já conhecidas.

Geralmente, para preparar amostras de leveduras, primeiro são obtidos os protoplastos que são posteriormente embebidos em agarose, seguindo-se o tratamento com detergentes e enzimas proteolíticas em temperaturas elevadas. Trabalhos recentes vêm simplificando o método de preparação das amostras, onde é necessário a obtenção de protoplastos (McCluskey et al.,1990) e o tratamento com enzimas proteolíticas em temperaturas elevadas (Miao et al., 1990) para a definição de bandas cromossômicas em gel de eletroforese.

Sheehan \& Weiss (1991) utilizaram o método de CHEF para identificar a presença de leveduras poliplóides que causavam alteração no sabor e aroma da cerveja. Com a utilização do método, foi possível encontrar padrões de 16 bandas para Saccharomyces cerevisiae, detectando ploidia da linhagem quando comparada com a original do estoque. Relataram ainda que não foi possível apresentar uma repetitibilidade satisfatória. 
Link \& Olson (1991) utilizaram o método CHEF para construir um mapa físico do genoma de Saccharomyces cerevisiae, com a separação de cromossomos e hibridização DNA-DNA. O método de eletroforese de proteínas apresenta satisfatória diferenciação entre linhagens de Saccharomyces cerevisiae, sendo um método rápido e fácil de detecção de contaminantes da fermentação (Tavares, 1992).

A técnica de eletroforese em campo pulsado possibilita o conhecimento do padrão de bandas de um produto de fusão interespecífico e permite identificar cromossomos paternos que foram mantidos no híbrido. A técnica surge também como um recurso importante na caracterização de leveduras, possibilitando um rápido avanço no conhecimento da diversidade genética a nível cromossômico e contribuindo ainda, com mais um parâmetro no controle de qualidade e taxonomia de leveduras e de outros fungos (Mills \& McCluskey, 1990; Naumov et al., 1992).

Lobrich et al. (1993) demonstraram que o tempo de pulso e a resistência do campo elétrico podem interferir na migração das bandas no gel podendo haver uma inversão de bandas como verificado como cromossomos IV e XII de Saccharomyces cerevisiae.

O avanço da eficiente técnica de eletroforese em campo pulsado, primeiramente desenvolvida em S. cerevisiae (Schwartz \& Cantor, 1984), tem surgido ser um recurso adicional para o estudo de genética básica em muitos organismos.

Basso et al. (1993) acompanharam mediante a utilização da técnica de separação eletroforética do DNA cromossômico intacto (técnica da cariotipagem), a permanência de linhagens industriais no processo fermentativo em diversos distúrbios. A técnica, como uma ferramenta de grande valia na diferenciação de gêneros, espécies, bem como de diferentes linhagens de uma mesma espécie, permitiu concluir que as leveduras iniciais (TA, NF e 
Fleischmann) não permaneciam nas dornas sendo completamente substituídas após 40 dias de processo.

\subsubsection{Caracterização de Leveduras Baseado na Capacidade de Reassociação DNA-DNA}

Barnett (1992) utilizando o critério de reassociação de DNA nuclear de diferentes linhagens e revisando a taxonomia do gênero Saccharomyces, considerou aqueles com cerca de 80 a 100\% de seqüências de base em comum como pertencentes àmesma espécie. Embora o alto grau de homologia do DNA de duas linhagens possa indicar um estreito relacionamento ancestral, valores baixos para esta homologia são provavelmente mais difíceis de interpretar.

Tavares et al. (1992) fizeram uma comparação utilizando três métodos (isoenzimas, eletroforese de proteínas totais e DNA fingerprinting, para a identificação de leveduras da indústria alcooleira pertencentes a espécie Saccharomyces cerevisiae e concluíram que os três métodos eram eficazes para a identificação de linhagens da mesma espécie e com isso, permitiram distinguir variações do próprio fermento ou aquela devido a contaminação.

Rearranjos cromossômicos também foram observados por Adams et al. (1992) em linhagens haplóides e diplóides de Saccharomyces cerevisiae principalmente eventos de translocações, duplicações e deleções. Tais rearranjos indicaram ocorrência de adaptação genética do meio. Esse foi um caminho que permitiu estudos sobre modificações estruturais no genoma das leveduras, as quais garantiam sua adaptação a novos ambientes contribuindo para sua evolução e garantindo sua sobrevivência.

Naumov et al. (1992) puderam demonstrar que as três espécies do gênero Saccharomyces: S.cerevisiae, S.paradoxus e S.bayanus, apresentaram 16 
cromossomos e revelaram também o baixo grau de homologia entre os genes estudados de Saccharomyces cerevisiae com as demais espécies.

Torok et al. (1992) observaram, em linhagens de Zygosaccharomyces, migração de bandas aneuplóides e poliplóides. Também foi demonstrado polimorfismo no comprimento de leveduras industriais, sugerindo rearranjos cromossomais tais como inserção, deleções, duplicações e translocações. Os autores sugeriram que estas técnicas moleculares poderiam ser usadas nos estudos de diversidade genética e também para a identificação de leveduras. A maior vantagem deste método de hibridização DNA-DNA foi não ser requerido o conhecimento da seqüência da sonda usada para a reação espécie específica, bastando saber a qual grupo de ligação pertence.

Em leveduras, caracterização genotípica vem sendo feita em espécies de Saccharomyes e Candida. O nível de diferenças entre DNAs de diferentes espécies de ambos os gêneros é detectado para a confirmação de espécies identificadas (Quesada et al., 1995). Também, novas espécies de leveduras vêm sendo identificadas, tendo o seu DNA comparado com espécies já conhecidas (Baleiras et al., 1995; Masneuf et al.,1996; Valente et al., 1996).

Segundo Hoog et al. (1998), os métodos moleculares são utilizados em grande escala para o estudo da biodiversidade em fungos. No caso de fungos de importância industrial, os métodos são aplicados em duas grandes áreas. A primeira, envolvendo a obtenção de dados mais precisos para a taxonomia, uma vez que métodos clássicos apresentam uma limitada resolução, como nos fungos leveduriformes que apresentam pouca variação morfológica. A segunda, para aqueles grupos variáveis e com espécies até então pouco descritas e, estão sendo reconhecidas como um conjunto de pequenas entidades. A segunda aplicabilidade é a filogenia, pois os métodos facilitam a construção de árvores filogenéticas, as quais podem servir como um modelo do suposto curso da evolução. 


\subsubsection{Aplicação de Marcadores Moleculares}

\subsubsection{RAPD}

O advento da técnica de PCR (Polymerase Chain Reaction) (Mullis \& Faloona, 1987) e seus posteriores avanços, utilizando uma enzima DNA polimerase termoestável e termocicladores programáveis com elevada capacidade de processamento, imprimiram grande automatização à síntese in vitro de DNA. A técnica de PCR consiste na síntese enzimática in vitro de um segmento de DNA, delimitado por um par de primers de seqüências específicas de nucleotídeos de fita simples. Primers são seqüências curtas de DNA (oligonucleotídeos), que pareiam com o DNA-molde e servem de iniciadores para a síntese de uma nova fita de DNA, as reações ocorrem em ciclos alternados de temperatura, sendo que cada ciclo do PCR envolve três etapas. Na primeira, ocorre a desnaturação da fita dupla de DNA, posteriormente, os primers se anelam æ̀̀ seqüências complementares específicas que flanqueiam o gene alvo, e então a nova fita de DNA é sintetizada a partir das extremidades 3' -OH livres dos primers, por meio da enzima DNA polimerase. Como cada ciclo é repetitivo várias vezes, a amplificação do DNA-alvo ocorre em progressão geométrica, requerendo uma quantidade muito pequena de DNA-molde.

A técnica de PCR consiste de uma reação de polimerização em cadeia para a amplificação de seqüência de DNA por uma reação enzimática primer dirigida (Ferreira \& Grattapaglia, 1998). Sendo assim, através da PCR, pode-se obter, in vitro um aumento da quantidade de uma determinada seqüência de DNA, representando então um grande recurso para o estudo destas seqüências, permitindo uma série de aplicações nas mais diferentes áreas da ciência. Em microrganismos, a PCR vem sendo aplicada na determinação de grupos taxonômicos. 
Entre os marcadores moleculares, o RAPD tem sido usado no estudo da variabilidade entre espécies (Molnár et al., 1996) e em nível de população (Uijthof et al., 1994).

Waugh \& Powell (1992) fizeram uma comparação entre os métodos RAPD e o RFLP para demonstrar suas características (Tabela 1).

Tabela 1. Comparação entre o RFLP e o RAPD.

\begin{tabular}{lcc}
\hline & RFLP & RAPD \\
\hline Parte do genoma analisado & $\begin{array}{c}\text { Baixas cópias de } \\
\text { regiões codificantes }\end{array}$ & Todo o genoma \\
Qualidade do DNA & Puro & Bruto \\
Quantidade do DNA & $2-10 \mu \mathrm{g}$ & $10-50 \mathrm{ng}$ \\
Uso de radioisótopos & Sim & Não \\
Tipo de sonda & Específico & Ao acaso \\
Dificuldade técnica & Intermediária & Baixa \\
\hline
\end{tabular}

A detecção e exploração de seqüências de polimorfismos de DNA ocorridos naturalmente representa um dos mais significativos desenvolvimentos na biologia molecular. O método RAPD tem sido bastante utilizado principalmente pela vantagem de ser simples e rápido (Tavares et al., 1992).

Segundo Bered et al. (1997), os marcadores genéticos poderão auxiliar na identificação de microrganismos através de suas diferenças genéticas. Estes marcadores podem ser divididos em morfológicos e moleculares (enzimáticos e de DNA). Os marcadores de DNA como o RFLP e o RAPD poderão contribuir através do mapeamento de espécies de interesse, a sua eficiência em caracterizar e agrupar genótipos diferentes de várias espécies com bastante precisão. 
Fenótipos moleculares, gerados por RAPD, podem servir para diagnosticar diferentes níveis taxonômicos. Considerando-se um determinado primer os produtos de amplificação via RAPD, podem ser classificados em dois grupos: variáveis (polimórficos) e constantes (não-polimórficos). Perfis de RAPD de representantes de vários gêneros podem conter bandas comuns a um outro gênero, enquanto outras bandas podem ser exclusivas. Se várias espécies pertencentes a esse gênero forem analisadas e uma das bandas exclusivas do gênero estiver presente em todas elas, pode-se concluir que esta banda é um marcador específico de gênero. Da mesma forma, quando se tem um perfil de RAPD de espécies de um mesmo gênero, algumas bandas poderão ser compartilhadas por algumas espécies, enquanto outras poderão ser exclusivas de uma dada espécie. Se vários indivíduos dessa espécie forem analisados e essa banda estiver presente em todos eles, pode-se concluir que é um marcador específico da espécie (Fungaro \& Vieira, 1998). Assim, os marcadores de RAPD podem ser utilizados para diagnóstico molecular de diferentes níveis taxonômicos. Fragmentos polimórficos detectados entre indivíduos de uma população também podem ser utilizados para se determinar o que se chama de identidade clonal, o que normalmente é requerido em estudos envolvendo organismos de reprodução assexual (marcadores clone-específico).

Em leveduras, RAPD e cariotipagem eletroforética foram utilizados para a caracterização de produtos de fusão de protoplastos e seus segregantes, detectando-se uma banda cromossomal nos produtos de fusão, presentes nas linhagens parentais e segregantes (Martins et al., 1998).

A tecnologia de PCR tem gerado diversas classes de marcadores moleculares que podem ser aplicados no estudo do DNA inteiro ou fragmentado. Um destes métodos foi denominado de RAPD (Willians et al. 1990) ou AP-PCR (Arbitrarily Primed Polimerase Chain Reaction), Welsh \& McClelland (1990), e é caracterizado pela polimerização de cadeia utilizando primers arbitrários. Estes 
métodos propõem que os oligonucleotídeos escolhidos ao acaso em uma seqüência de DNA, misturados com DNA genômico e DNA polimerase termoestável, submetidos a ciclos de temperaturas controláveis como os descritos para PCR, iniciassem a amplificação do DNA. Ou seja, os componentes necessários àreação de polimerização eram os mesmos descritos pela PCR. Os fragmentos amplificados podiam ser visualizados em gel de agarose revelado com brometo de etídio (Williams et al., 1990) ou através da utilização de desoxiribonucleotídios (dNTPs) marcados radioativamente.

O RAPD é interessante porque requer uma pequena quantidade de DNA que revela um grande número de marcas polimórficas, é rápido e automatizado. O uso de marcadores RAPD tem-se mostrado útil nos estudos de microrganismos onde não se tem muita informação genética. A técnica é baseada na amplificação de fragmentos não específicos de DNA, em reações sucessivas de polimerização. Como descrito por Williams et al. (1990), os oligonucleotídeos são construídos com seqüências aleatórias, ao contrário da PCR, revelando polimorfismos em toda a extensão do genoma. Tais polimorfismos são reconhecidos pela presença de um fragmento amplificado em um dos genomas em relação a ausência deste mesmo fragmento em outro.

\subsubsection{RNA Ribossomal}

A síntese de proteínas depende da participação do RNA ribossômico (rRNA) no processo de tradução da informação genética. A codificação do rRNA é feita em regiões específicas do genoma pelo chamado DNA ribossômico, muitas vezes visíveis com auxílio de microscópios, as chamadas "regiões organizadoras de nucléolo" (NOR). O número de NOR é aparentemente característico para cada espécie.

O DNA ribossomal contido nas regiões organizadoras do nucléolo tem sido objeto de um grande número de estudos, com diversas aplicações em 
genética, evolução e melhoramento. Tal interesse está relacionado à estrutura desta região. O rDNA é caracteristicamente repetitivo, uma propriedade que permite uma série de aplicações. O fato de ser repetitivo implica que uma certa estrutura ou seqüência de nucleotídeos ( "core sequence") se repita lado a lado (em "tandem") inúmeras vezes.

Sendo assim, por ser repetitivo e por estar situado em regiões específicas do genoma, a proporção de rDNA é, em geral, alta em relação ao conteúdo total de DNA da espécie. O DNA total da espécie inclui DNA nuclear, ribossômico, mitocondrial e plastidial. O rDNA é encontrado no núcleo e também no citoplasma celular.

A função do rDNA, ao contrário de outras seqüências repetitivas que aparentemente não tem função conhecida no genoma, é a codificação do rRNA, implicado no processo de tradução de proteínas. Em geral, as regiões 26S, $18 \mathrm{~S}$ e 5,8S das unidades de repetição não apresentam variação de seqüência, enquanto que as regiões internas que são transcritas (ITS) variam grandemente. Esta característica tem sido utilizada para obter polimorfismo de comprimento de fragmento nos locos de rDNA (RFLP) através do uso de enzimas de restrição. $O$ número de cópias de uma determinada seqüência de rDNA também tem sido utilizado em tais estudos, bem como variações na seqüência de nucleotídeos das unidades de repetição. Os dados gerados através desta técnica têm sido utilizados para estudos de filogenia e evolução, bem como para caracterização de germoplasma e análise de diversidade genética (Ferreira \& Grattapaglia, 1998). 


\section{MATERIAL E MÉTODOS}

\subsection{Microrganismos Utilizados}

As leveduras utilizadas para o desenvolvimento deste trabalho foram as linhagens IZ-987 e IZ-259 obtidas da coleção do Departamento de Agroindústria, Alimentos e Nutrição da Escola Superior de Agricultura "Luiz de Queiroz" da Universidade de São Paulo e as linhagens PE-2 e CR-1 cedidas gentilmente pela FERMENTEC S/C Ltda, localizadas em Piracicaba (SP).

A levedura em estudo foi a linhagem IZ-987 que apresenta a característica de não produzir $\mathrm{H}_{2} \mathrm{~S}$, ser floculante e produzir álcool de forma satisfatória, tendo sido utilizada na produção de aguardente de caldo de cana-de-açúcar (Ribeiro, 1997). As linhagens PE-2 e IZ-259 foram utilizadas como leveduras padrões pertencentes ao gênero Saccharomyces cerevisiae e a levedura CR-1 como padrão de Saccharomyces bayanus.

Foi também utilizada a linhagem $\mathrm{DH} 5 \alpha$ de Escherichia coli no experimento de transformação bacteriana, para obtenção de um grande número de plasmidio contendo o inserto de interesse.

\subsection{Meios de Cultura}

Os meios de cultura foram esterilizados em autoclave, a $121^{\circ} \mathrm{C}$, a $1 \mathrm{~atm}$ por 15 minutos. 
3.2.1 Meio GYP "Sabouraud" (Arx \& Schipper, 1978)

Glicose................................ $20 \mathrm{~g}$

Extrato de levedura.................... $5 \mathrm{~g}$

Peptona.............................................10 g

Água destilada................................1000 mL

Para o preparo de meio sólido, foram adicionados $20 \mathrm{~g}$ de ágar.

Este meio foi utilizado para a manutenção de culturas, multiplicação das células e preparo do inoculo nos ensaios de crescimento.

3.2.2 Meio CMA - Corn meal ágar (Bernhardt, 1946)

Corn meal ágar (Difco)................ $17 \mathrm{~g}$

Água destilada............................. $1000 \mathrm{~mL}$

Preparado de acordo com as especificações do fabricante. Meio de cultura para esporulação e determinação da habilidade para formar ascósporos ou basidiosporos.

3.2.3 Meio Acetato-ágar (Kreger-van Rij, 1984b)

Acetato de sódio $3 \mathrm{H}_{2} \mathrm{O} \ldots \ldots \ldots \ldots \ldots \ldots \ldots . . .5 \mathrm{~g}$

Ágar..................................... $20 \mathrm{~g}$

Água destilada.............................. $1000 \mathrm{~mL}$

Este meio foi utilizado para a produção de esporos. O acetato-ágar é efetivo, principalmente, para espécies de Saccharomyces.

3.2.4 Meio Gorodkowa-ágar (Kreger-van Rij, 1984b)

Glicose........................................ $1 \mathrm{~g}$

Peptona......................................... $10 \mathrm{~g}$

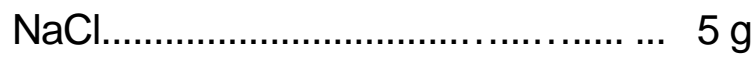


Ágar........................................ $20 \mathrm{~g}$

Água destilada............................ $1000 \mathrm{~mL}$

Meio utilizado para a produção de ascósporos.

\subsubsection{Meio Acetato de Potássio}

Rafinose....................................... $0,22 \mathrm{~g}$

Acetato de Potássio........................... $30 \mathrm{~g}$

Ágar............................................. $20 \mathrm{~g}$

Água destilada............................. $1000 \mathrm{~mL}$

Meio utilizado para a produção de ascósporos.

3.2.6 Meio Basal para testes de fermentação (Wickerham, 1946)

Extrato de levedura.......................... 4,5 g

Peptona........................................ 7,5 g

Água destilada...............................1000 mL

Foi adicionado azul de bromotimol até a coloração verde-garrafa, este meio foi utilizado para determinar a habilidade das linhagens de fermentar diferentes carboidratos.

3.2.7 Meio de Carbonato de Cálcio(CaCO$\left.{ }_{3}\right)$ ágar (Kreger-van Rij, 1984b)

Extrato de levedura....................... $5 \mathrm{~g}$

Carbonato de cálcio..................... $5 \mathrm{~g}$

Glicose......................................... $50 \mathrm{~g}$

Ágar......................................... $20 \mathrm{~g}$

Água destilada............................ $1000 \mathrm{~mL}$

Este meio foi utilizado para a produção de ácido a partir da glicose. 


\subsection{Soluções e tampões}

\subsubsection{Solução de Brometo de Etídio}

Brometo de etídio............................ $0,01 \mathrm{~g}$

Água destilada................................ $10 \mathrm{~mL}$

Esta solução foi agitada por várias horas e estocada à $4^{\circ} \mathrm{C}$. No momento do uso, foi diluído $3 \mu \mathrm{L} \mathrm{em} 100 \mathrm{~mL}$ de tampão TBE $(1 \mathrm{x})$.

\subsubsection{Fenol}

Foi utilizado fenol equilibrado de origem comercial uc-DNA / ULTRA CHEM (Sambrook et al, 1989), para precipitação de proteínas nas extrações de DNA.

\subsubsection{Clorofane}

Para preparação do clorofane, foi misturado um volume de fenol com um volume de clorofórmio (1:1). A solução foi mantida em frasco escuro e sob refrigeração formando duas fases. No momento do uso foi utilizada a fração inferior.

\subsubsection{Clorofil}

Foram misturados clorofórmio e álcool isoamílico na proporção de 24:1 $(\mathrm{v} / \mathrm{v})$. A solução foi mantida em frasco escuro e sob refrigeração.

\subsection{5 Ácido Etilenodiamino tetraacético (EDTA) 0,5M pH 8,0}

EDTA ........................................ 37,22 g

Água destilada............................. $200 \mathrm{~mL}$

$\mathrm{O} \mathrm{pH}$ foi ajustado para 8,0 com pastilhas de $\mathrm{NaOH}$. A solução foi autoclavada e mantida a $4^{\circ} \mathrm{C}$.

\subsubsection{Tris $-\mathrm{HCl} 1 \mathrm{M}$ pH 8,0}


Trizma base.

$121,1 \mathrm{~g}$

Água destilada............................. $1000 \mathrm{~mL}$

$\mathrm{O} \mathrm{pH}$ foi ajustado para $8,0 \mathrm{com} \mathrm{HCl}$ concentrado. A solução foi autoclavada e mantida à $4^{\circ} \mathrm{C}$.

\subsection{7 $\mathrm{NaCl}(5 \mathrm{M})$}

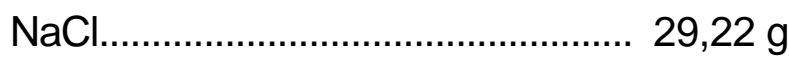

Água destilada............................... $100 \mathrm{~mL}$

A solução foi autoclavada e mantida à $4^{\circ} \mathrm{C}$.

\subsection{8 $\mathrm{NaCl}(3 \mathrm{M})$}

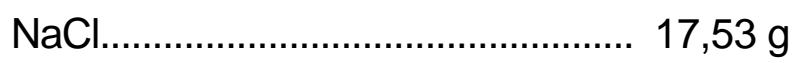

Água destilada.............................. $100 \mathrm{~mL}$

A solução foi autoclavada e mantida à $4^{\circ} \mathrm{C}$.

\subsubsection{Dodecil Sulfato de Sódio (SDS) $10 \%$}

Dodecil Sulfato de Sódio................... $20 \mathrm{~g}$

Água destilada............................. $200 \mathrm{~mL}$

A solução foi autoclavada e deixada em temperatura ambiente.

\subsubsection{Tampão Tris-EDTA (TE)}

Tris $\mathrm{HCl} 1 \mathrm{M} \mathrm{pH} \mathrm{8,0} \mathrm{(item} \mathrm{3.3.6)..........} 1 \mathrm{~mL}$

EDTA 0,5M pH 8,0 (item 3.3.5).......... 0,2 mL

O volume foi completado para $100 \mathrm{~mL}$ com água destilada esterilizada.

\subsection{Tampão de Extração de DNA}


Tris $\mathrm{HCl} 1 \mathrm{M} \mathrm{pH} 8,0$ (item 3.3.6)....... $40 \mathrm{~mL}$

$\mathrm{NaCl} 5 \mathrm{M} \mathrm{pH} 8,0$ (item 3.3.7)............ $10 \mathrm{~mL}$

EDTA 0,5 M pH 8,0 (item 3.3.5)........ $10 \mathrm{~mL}$

SDS $10 \%$ (item 3.3.9).................... $20 \mathrm{~mL}$

Água destilada esterilizada............ $120 \mathrm{~mL}$

A solução foi preparada no momento do uso.

\subsubsection{Tampão da Amostra (6x)}

Azul de bromofenol............................ 0,25 mL

Polimero sintético de sacarose (Ficoll). $15 \mathrm{~g}$

Água destilada ................................. $100 \mathrm{~mL}$

O tampão foi estocado à $4^{\circ} \mathrm{C}$.

\subsubsection{Tampão TBE (10x)}

Trizma base

$54,0 \mathrm{~g}$

$\mathrm{H}_{3} \mathrm{BO}_{3}$

$27,5 \mathrm{~g}$

EDTA.

$4,65 \mathrm{~g}$

Água destilada $500 \mathrm{~mL}$

No momento do uso foram feitas as diluições para se obter TBE 1X.

\subsubsection{Gel de Agarose para Quantificação de DNA}

Agarose A-0169 (Sigma)..................... 0,8 g

TBE (1x) (item 3.3.13 ).....................100 mL

\subsubsection{Gel de Agarose para RAPD}

Agarose A-0169 (Sigma).................... 2,1 g

TBE (1x) (item 3.3.13 ).................. $150 \mathrm{~mL}$

\subsubsection{Gel de Agarose para PCR}


Agarose A-0169 (Sigma) ................. 1,2 g

TBE (1x) (item 3.3.13 )................. $100 \mathrm{~mL}$

\subsection{Metodologia}

\subsubsection{Purificação das Culturas}

Para identificação e classificação as linhagens de leveduras foram suspensas em tubos de ensaio contendo água destilada estéril e inoculadas em placas de Petri contendo meio de GYP "Sabouraud" ágar e incubadas a $27^{\circ} \mathrm{C}$ por 48 a 72 horas. Decorrido o período de incubação, uma colônia representativa de cada placa foi repicada em tubos com meio GYP "Sabouraud" ágar inclinado e mantido como cultura estoque a $4^{\circ} \mathrm{C}$ e reativada periodicamente.

\subsubsection{Características Morfológicas}

\subsubsection{Crescimento em Meio Líquido}

Para a verificação das características das leveduras quanto ao crescimento em meio líquido as linhagens foram inoculadas em tubos de ensaio contendo $9 \mathrm{~mL}$ de meio GYP "Sabouraud" e incubados a $27^{\circ} \mathrm{C}$ por 3 a 5 dias. Após a incubação foi observada a característica de formação de película.

\subsubsection{Crescimento em Meio Sólido}

Para estudo das características morfológicas em meio sólido as culturas foram inoculadas em placas de Petri contendo meio sólido GYP "Sabouraud" ágar e incubadas a $27^{\circ} \mathrm{C}$ por 3 a 7 dias. Foram observadas as características das colônias como coloração, brilho, textura, superfície, forma, margem, elevação, observadas a olho nu. As características da forma das células e o tipo de divisão celular foram observadas em microscópio, utilizando-se aumento de 1.000 vezes. 


\subsubsection{Microcultivo}

A formação de pseudomicélio e micélio verdadeiro foi verificada de acordo com o método de Castro (1995). As culturas de leveduras foram inoculadas sobre lâminas cobertas com uma pequena quantidade de meio CMA (Corn Meal Ágar - DIFCO) na forma de 3 riscos e recobertas com uma lamínula estéril incubadas dentro de uma placa de Petri a $27^{\circ} \mathrm{C}$. Após 5 a 7 dias de incubação as lâminas foram observadas em microscópio óptico (aumento $1.000 x)$.

\subsubsection{Características da Reprodução Sexuada}

A formação de ascos e ascósporos foi verificada inoculando-se culturas de leveduras com 48 horas previamente desenvolvidas em meio GYP ágar a $30^{\circ} \mathrm{C}$ em tubos com meio inclinado de Acetato-ágar (Kreger-van Rij, 1984b), Gorodkowa-ágar e Acetato de Potássio. Após a incubação a $27^{\circ} \mathrm{C}$ por 7 a 21 dias, foi verificada a produção de ascósporos ao microscópio óptico, em preparação àfresco, anotando-se o tamanho e a forma dos ascos e ascósporos, o número de ascósporos por asco, bem como a presença ou ausência de conjugação. No caso da não produção de esporos, a cultura foi novamente incubada e lâminas foram preparadas periodicamente para a verificação destas características.

\subsection{Características Fisiológicas e Bioquímicas}

\subsubsection{Fermentação de Carboidratos}

As linhagens foram testadas quanto a habilidade de fermentar sacarose, glicose, galactose, lactose, rafinose, maltose, celobiose e melibiose, como sugerido por Wickerham e citado por Kreger-van Rij, 1984b. Para a sacarose, glicose, galactose, lactose, maltose, celobiose e melibiose utilizou-se solução a 
$6 \%$ e para a rafinose solução a $12 \%$, esterilizados à vácuo por filtração em membranas de 0,22 $\mu \mathrm{m}$ pelo sistema asséptico "sterifil" (Millipore).

Preparação do inóculo: uma suspensão de células de leveduras foi preparada a partir de células cultivadas por 24 a 48 horas em meio GYP ágar a $30^{\circ} \mathrm{C}$. A massa celular retirada, com alça, do tubo de ensaio, foi ressuspensa em $2 \mathrm{~mL}$ de água destilada estéril. A concentração celular foi avaliada através do Cartão de Wickerham (com 3 linhas pretas em um cartão branco). Trata-se de uma técnica que permite uma estimativa da densidade de células de uma suspensão, tendo sido estabelecidos quatro níveis de concentração celular com avaliação feita comparativamente, observando-se o crescimento baseado no seguinte critério (Castro,1995).

0: Poucas células (linhas totalmente visíveis)

1: Densidade fraca (linhas visíveis; um pouco embaçadas)

2: Densidade média (linhas embaçadas e difusas)

3: Densidade forte (linhas não visíveis)

A capacidade fermentativa das linhagens foi verificada em tubos de ensaio com tubos de Durham invertidos, contendo $2 \mathrm{~mL}$ de Meio basal e solução de azul de bromotimol até a coloração verde-garrafa, acrescida de $1 \mathrm{~mL}$ do carboidrato em estudo. Os tubos foram inoculados com $0,1 \mathrm{~mL}$ de uma suspensão celular (densidade forte), crescidas em GYP "Sabouraud" ágar e incubadas a $27^{\circ} \mathrm{C}$ por 48 horas. As leituras foram realizadas periodicamente observando-se a produção de ácido através da mudança de coloração do meio basal para amarelo, e a formação de gás capturado no interior do tubo de Durham. As observações foram feitas por um período máximo de 21 dias (Castro,1995).

Para efeito de identificação só foram considerados positivos os tubos de Durham que apresentaram produção de gás e negativo quando o tubo de Durham não apresentava produção de gás. A quantidade de gás produzida indica 0 potencial fermentativo das linhagens e o registro dos resultados foi feito considerando-se: 
- Positivo: quando o tubo de Durham continha de 1/3 a 3/3 de gás

- Negativo: quando não havia a produção de gás.

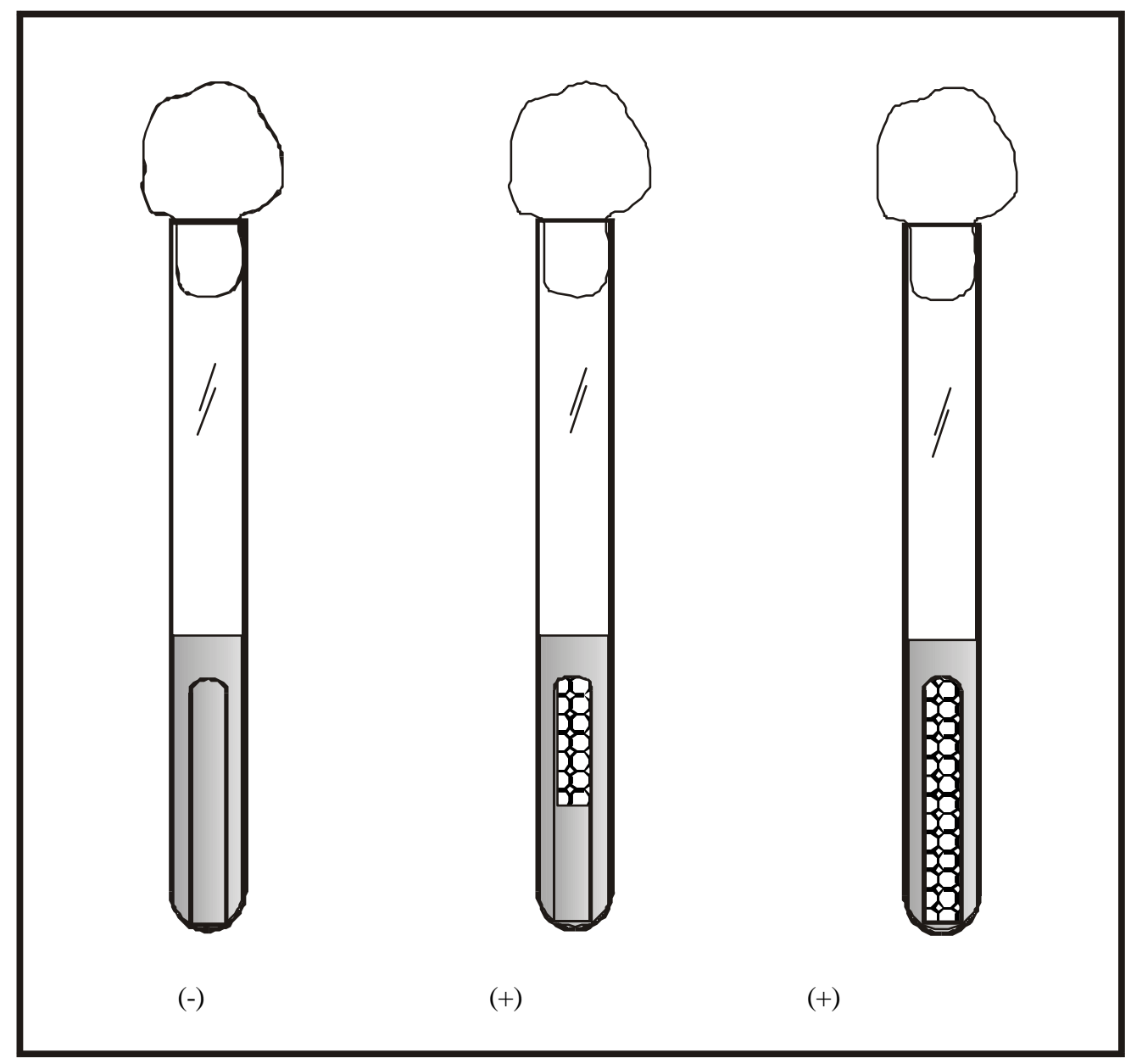

Figura 1 - Teste de fermentação de carboidratos.

Legenda: (-) ausência de crescimento e compostos não assimilados; (+) presença de crescimento.

\subsubsection{Assimilação de Compostos de Carbono}


Para a caracterização das linhagens foram testadas as seguintes fontes de carbono: glicose, galactose, sacarose, maltose, celobiose, lactose, melibiose, rafinose, D-xilose, ribitol, D- manitol, inositol e eritritol.

As fontes de carbono foram preparadas em soluções estoque a $5 \%$, com exceção da rafinose a $10 \%$ e foram esterilizadas por filtração à vácuo, em membranas de 0,22 $\mu \mathrm{m}$ pelo sistema asséptico "sterifil" (Millipore).

A inoculação foi feita em tubos de ensaio com $2 \mathrm{~mL}$ de água destilada estéril, $0,25 \mathrm{~mL}$ de YNB (Yeast Nitrogen Base) a 6,7\%, 0,25 mL da solução estoque dos compostos de carbono e $0,05 \mathrm{~mL}$ da suspensão de células (densidade forte) através do Cartão de Wickerham. Foram inoculados também tubos com YNB (sem fonte de carbono) como controle negativo. Os tubos foram incubados à $27^{\circ} \mathrm{C}$ e avaliados após 7,14 e 21 dias, observando-se o crescimento celular através do Cartão de Wickerham (Castro, 1995)..

\subsubsection{Assimilação dos Compostos de Nitrogênio}

A capacidade de utilizar compostos nitrogenados como única fonte de nitrogênio é de grande valor para a identificação de espécies de leveduras. Foram utilizadas as seguintes fontes de nitrogênio:

Nitrato de potássio. $0,78 \mathrm{~g} / 100 \mathrm{~mL}$

Nitrito de sódio $0,26 \mathrm{~g} / 100 \mathrm{~mL}$

Lisina. $0,56 \mathrm{~g} / 100 \mathrm{~mL}$

Etilamina $0,64 \mathrm{~g} / 100 \mathrm{~mL}$

As fontes de nitrogênio foram esterilizadas separadamente, por filtração à vácuo, em membranas de 0,22 $\mu \mathrm{m}$, pelo sistema asséptico "sterifil" (Millipore).

A inoculação foi feita em tubos com $2 \mathrm{~mL}$ de água destilada esterilizada, acrescido de 0,25 mL de YCB (Yeast Carbon Base a 11,7\%), 0,25 mL da solução estoque das fontes de nitrogênio e $0,05 \mathrm{~mL}$ da suspensão de células (densidade media). Os tubos foram incubados à $27^{\circ} \mathrm{C}$ e avaliados após 7, 14 e 21 dias (Castro,1995). 
Para efeito de identificação, foram considerados como positivos os resultados 2 e 3 . Os resultados 0 e 1 foram considerados como negativos (item 3.5.1).

\subsubsection{Crescimento à Temperatura de $37^{\circ} \mathrm{C}$}

Temperaturas entre 20 e $30^{\circ} \mathrm{C}$ são ideais para o crescimento de muitas espécies de leveduras. No entanto, algumas espécies com habitats específicos e restritos crescem em temperaturas superiores ou inferiores à média. As culturas foram repicadas em tubos com meio inclinado GYP ágar e incubadas a $37^{\circ} \mathrm{C}$ por 3 a 4 dias. Observou-se após o período de incubação se houve crescimento na superfície do meio.

\subsubsection{Produção de Ácido a partir da Glicose}

A capacidade de produção de ácido a partir da glicose foi verificada pela inoculação das culturas mediante estrias em meio de $\mathrm{CaCO}_{3}$ ágar. Após 7 dias de incubação a $27^{\circ} \mathrm{C}$, o ácido formado pelas linhagens é capaz de dissolver o carbonato de cálcio disperso no meio de cultura, produzindo halos translúcidos (Castro,1995).

\subsection{Técnicas Moleculares}

\subsubsection{Extração de DNA das Linhagens (Raeder \& Broda, 1985)}

As leveduras foram crescidas em $100 \mathrm{~mL}$ de meio GYP "Sabouraud" (item 3.2.1) por 15 horas a $30^{\circ} \mathrm{C}$ sob agitação constante (150 rpm). Após o crescimento, foram transferidas para tubos plásticos de $15 \mathrm{~mL}$ com tampa e centrifugadas a $7000 \mathrm{G}$ por 6 minutos. O sobrenadante foi descartado e a massa celular transferida para um tubo de microcentrífuga, contendo o mesmo volume de sílica (1:1) e macerado com ajuda de um pistilo. 
Após o maceramento foi adicionado 2,1 $\mathrm{mL}$ de tampão de extração (item 3.3.11). Esta mistura foi incubada por $15 \mathrm{~min}$ a $65^{\circ} \mathrm{C}$. Após o período de incubação foi adicionado um volume igual de fenol (item 3.3.2) e misturadas as fases, sendo a seguir centrifugadas a $11600 \mathrm{G}$ por $10 \mathrm{~min}$ em microcentrífuga. A fase fenólica foi desprezada e àfase aquosa foi acrescentado um volume igual de clorofane (item 3.3.3). As fases foram novamente misturadas e centrifugadas como descrito anteriormente. A fase fenólica foi desprezada e foi adicionada à fase aquosa um volume de clorofil (item 3.3.4). A solução foi novamente homogeneizada e centrifugada. Após a centrifugação, a fase aquosa foi coletada e adicionada de $\mathrm{NaCl}$ na concentração final de $3 \mathrm{M}$. Foram adicionados dois volumes de etanol absoluto e resfriado a $-20^{\circ} \mathrm{C}$ por $5 \mathrm{~min}$. O DNA foi precipitado por meio de centrifugação a $11600 \mathrm{G}$ por $15 \mathrm{~min}$, sendo o sobrenadante descartado e o precipitado de DNA lavado em álcool 70\%. Após a secagem do DNA àtemperatura ambiente, o mesmo foi ressuspenso em $200 \mu \mathrm{L}$ de tampão TE (item 3.3.10) e quantificado em gel de agarose $(0,8 \%)$ com dois padrões de DNA lambda em concentração de $50 \mathrm{ng} / \mu \mathrm{L}$ e $100 \mathrm{ng} / \mu \mathrm{L}$.

\subsubsection{Análise de Polimorfismo de DNA Amplificado ao Acaso-RAPD (Random Amplified Polimorphic DNA)}

As amplificações foram feitas em volume de $25 \mu \mathrm{L}$ contendo, $2,5 \mu \mathrm{L}$ de Tris-HCL, $2 \mu \mathrm{L}$ de $\mathrm{MgCl}_{2}, 2,5 \mu \mathrm{L}$ de dNTP, $2,5 \mu \mathrm{L}$ de primer, 0,2 $\mu \mathrm{L}$ de Taq DNA Polimerase (Gibco - BRL) e $5 \mu \mathrm{L}(2,5 \mathrm{ng})$ de DNA genômico.

Os primers utilizados, foram OPAX-17 e OPB-11 sintetizados pela OPERON TECHNOLOGIES, INC.(Williams, et al.1990).

As amplificações foram realizadas em termociclador (PTC-100 ${ }^{\mathrm{TM}}$ da MJ RESEARCH INC) programado para realizar uma desnaturação inicial a $94^{\circ} \mathrm{C}$ por 5 min, seguido de 40 ciclos de 1 min a $92^{\circ} \mathrm{C}, 1$ min a $35^{\circ} \mathrm{C}$ e 2 min a $72^{\circ} \mathrm{C}$, com uma extensão final de 5 min a $72^{\circ} \mathrm{C}$. 
Os fragmentos amplificados foram separados em gel de agarose $1,4 \% \mathrm{em}$ tampão TBE a $2.5 \mathrm{~V} / \mathrm{cm}$. Foi utilizado DNA de lambda clivado com enzima de restrição Hind III como marcador de peso molecular. O gel foi corado com solução de brometo de etídio (item 3.3.1) por 20 min e descorado em água por 30 min e fotografado em transluminador de luz ultravioleta.

\subsubsection{Método de Análise dos Dados}

Os dados de RAPD foram transformados em variáveis binárias, ou seja, o número zero significou ausência de bandas e o número 1 representou a presença de bandas e analisados pelo programa NTSYS-pc. Este programa produziu uma matriz quantitativa com os dados introduzidos, utilizando o coeficiente Jaccard. A construção do dendrograma foi realizada através do (UPGMA-Unweighted pair group method with aritmetic average) método de agrupamento pareado sem peso com significado aritmético. $O$ dendrograma agrupou as linhagens, mostrando 0 nível de similaridade genética entre elas.

\subsubsection{Análise de Polimorfismo Cromossomal por Eletroforese de Campo} Alternado -TAFE (Blodin \& Vézinhet, 1988)

A análise de polimorfismo cromossomal das leveduras por eletroforese de campo alternado foi realizado no Departamento de Ciências Biológicas da Escola Superior de Agricultura "Luiz de Queiroz" da Universidade de São Paulo.

Os cultivos foram realizados em meio GYP "Sabouraud" ágar, por 48 horas a $30^{\circ} \mathrm{C}$, em placas de Petri. Os moldes para a confecção de plugs mais a solução de lise CPES (Ácido cítrico 0,210 g; $\mathrm{Na}_{2} \mathrm{HPO}_{4}$ 0,426 g; EDTA.Na $0,186 \mathrm{~g}$; Sorbitol 5,630 g; Dithiothreitol $0,020 \mathrm{~g}$ ) contendo "lysing enzymes", foram preparados em câmara de fluxo. Com arames de ponta curvada, foram coletadas as colônias individualmente e depositadas, cada uma dentro de um poço, no molde de confecção dos plugs. As mesmas foram ressuspensas na solução de 
lise, e homogeneizadas rapidamente com o próprio arame utilizado na coleta das colônias, deixando-se solidificar a temperatura ambiente por 30 minutos.

Os plugs foram transferidos para tubos de vidro contendo CPE (Ácido cítrico 1,68 g; $\mathrm{Na}_{2} \mathrm{HPO}_{4} 3,41 \mathrm{~g}$; EDTA.Na $21,49 \mathrm{~g}$ ) e mantidos por 4 horas a $28^{\circ} \mathrm{C}$, adicionando-se a solução 3 contendo proteinase $\mathrm{K}$; os tubos foram tampados com papel aluminio e mantidos em banho-maria por 16 horas a $50^{\circ} \mathrm{C}$. Posteriormente foi removida a solução de desproteinização e substituída com 1 $\mathrm{mL}$ de EDTA (e lavados 3 vezes por 20 minutos a $50^{\circ} \mathrm{C}$ e 5 vezes por 5 minutos a temperatura ambiente e uma última lavagem com $1 \mathrm{~mL}$ de TE).

Os plugs contendo amostras de DNA íntegro das leveduras, foram inseridos nas canaletas do gel de agarose 1\% (Agarose A-0169 1g; TBE $100 \mathrm{~mL}$ ) e selados com a mesma agarose. O gel foi transferido para câmara do equipamento GENE-LINE, contendo o tampão TAFE ( Tris 24,2 g; EDTA 2,9 g; Ácido acético $5,0 \mathrm{~mL}$ ) previamente resfriado a $14^{\circ} \mathrm{C}$.

As condições de corrida para a separação do DNA cromossômico foram realizadas a $220 \mathrm{~V}$, em 17 horas com pulsos de 60 seg. e 1 hora com pulsos a 15 seg. Após o término da corrida o gel foi removido da câmara e corado com brometo de etídio por aproximadamente 30 minutos e fotografado sob transluminador de ultravioleta e filtro laranja, para posterior analise do número de bandas.

\subsubsection{Sequenciamento do DNA Ribossomal (rDNA) da Levedura IZ-987}

Fragmentos de rDNA foram amplificados com os pares de primers ITS1 (5'-TCCGTAGGTGAACCTGCGG-3') e ITS4 (5'-TCCTCCGCTTATTGATATGC 3'). Para a reação de PCR foi utilizado um volume de $24 \mu \mathrm{L}$, contendo $3 \mu \mathrm{L}$ de Tampão da Enzima; 1,0 $\mu \mathrm{L}$ do primer ITS1 e do primer ITS4; $2,4 \mu \mathrm{L}$ de cada dNTPs (Gibco BRL-Life Technologies); 2,4 $\mu \mathrm{L}$ de $\mathrm{MgCl}_{2} ; 0,18 \mu \mathrm{L}$ de Taq DNA polimerase (Gibco) e foi adicionada uma reação sem DNA como controle. Foi utilizado um termociclador Gene AMP PCR System 9700 (Perkin Elmer), o qual 
foi programado para gerar uma desnaturação de 40 ciclos de 1 min a $94^{\circ} \mathrm{C}, 1 \mathrm{~min}$ a $58^{\circ} \mathrm{C}, 2$ min a $72^{\circ} \mathrm{C}$, com uma extensão final de 5 min a $72^{\circ} \mathrm{C}$.

Uma alíquota de $5 \mu \mathrm{L}$ do produto foi aplicado no gel de agarose $(1,2 \%)$ corado com brometo de etídio e fotografado sob luz ultravioleta (Mullis \& Faloona, 1987).

Após a amplificação o produto de PCR foi purificado com o kit GF PCR (Amersham Pharmacia Biotech) e clonado no plasmidio pGEM-T (Promega Madison) de acordo com as instruções do fabricante. Após transformação em $E$. coli $(\mathrm{DH} 5 \alpha)$ o plasmídeo foi extraído por lise alcalina e analisado em gel de agarose $1,2 \%$. A confirmação da presença do inserto foi realizada por meio de clivagem com a enzima de restrição Eco RI (Life Technologies) e observação de um fragmento de tamanho aproximado de $620 \mathrm{pb}$. A amostra contendo o inserto de tamanho esperado foi seqüenciada em sequenciador 377 Applied Biosystems no Departamento de Entomologia, Fitopatologia e Zoologia Agrícola da Escola Superior de Agricultura "Luiz de Queiroz", da Universidade de São Paulo.

A seqüência do fragmento do gene que codifica a subunidade $18 \mathrm{~S}$ rRNA, ITS1, 5,8S rRNA, ITS2 e parte do gene que codifica a subunidade 28S rRNA foi analisada no programa BLAST (htp://ncbi.nlm.nih.gov), comparando-as com as seqüências depositadas no Gene Bank. 


\section{RESUltados E discussão}

\subsection{Identificação Sistemática}

\subsubsection{Testes Morfológicos e Fisiológicos}

A morfologia assim como a fisiologia são imprescindíveis num estudo sistemático pois representam expressões da potencialidade do organismo.

O meio GYP ágar, indicado para o crescimento das células, evidenciou as diferenças morfológicas das colônias com uma variação de brilho, superfície, forma e margem. Foram observadas colônias brancas e cremes, brilhantes e opacas, superfícies lisas e rugosas, formas circulares e ovais, margens inteiras e onduladas (Figura 2). Microscopicamente as linhagens avaliadas apresentaram reprodução assexuada por brotamento multipolar, produziram ascos persistentes com esporos esféricos não conjugados, em número de 2 a 4 ascósporos por asco (Figuras 3 e 4).

A linhagem IZ-987 apresentou colônias de coloração creme, opacas com margem ondulada, textura butirosa com elevação maminolada e superfície estriada; ausência de pseudomicélio e micélio verdadeiro; apresentou crescimento lento a $37^{\circ} \mathrm{C}$ e formação de película em meio líquido. Microscopicamente a linhagem apresentou células circulares com reprodução assexuada por brotamento multipolar e não foi possível observar formação de ascósporos, o que dificultou a classificação da linhagem, devido esta característica ser importante para a definição de gênero. 


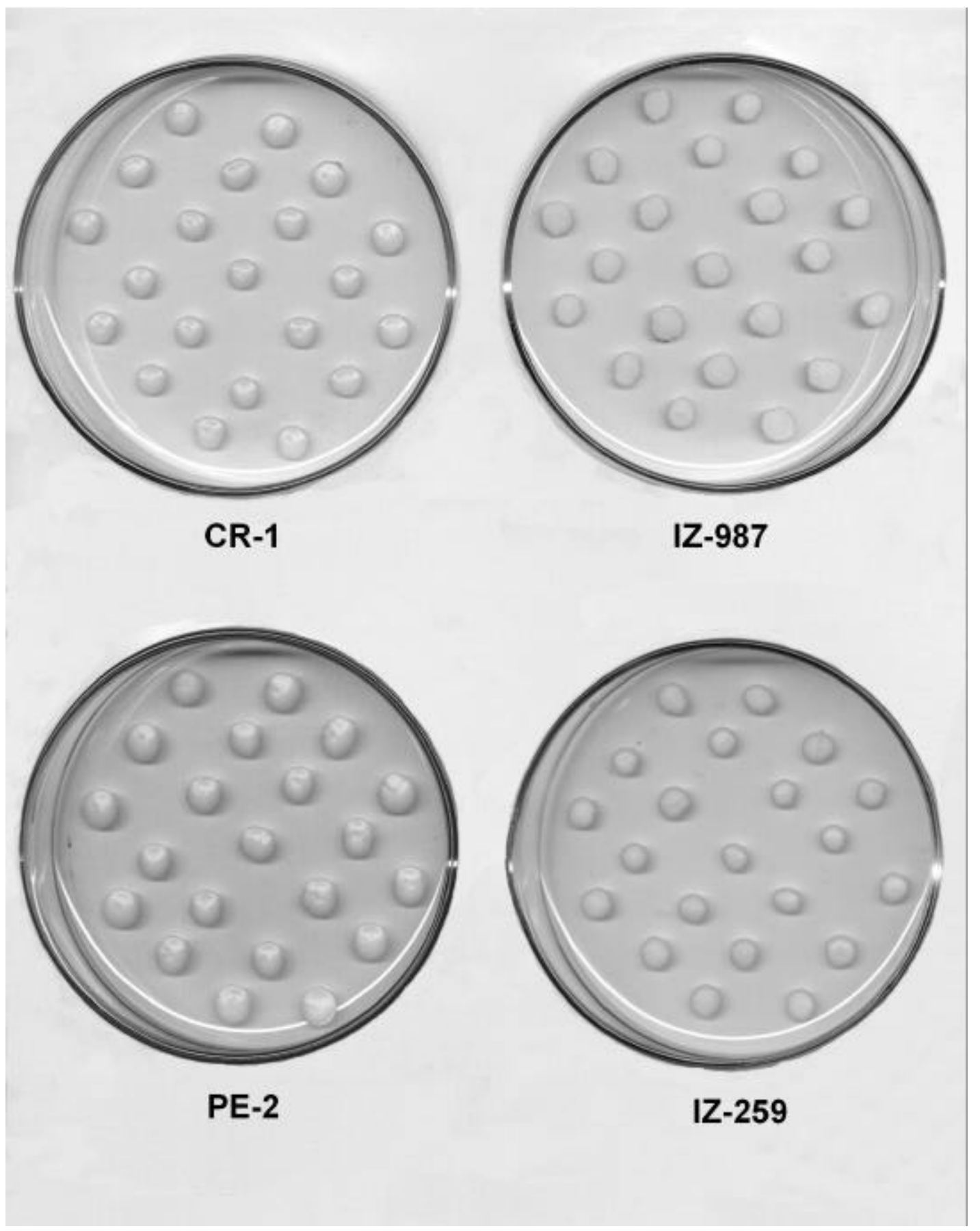

Figura 2 - Morfologia das colônias das linhagens após 6 dias de incubação em meio GYP ágar, a $30^{\circ} \mathrm{C}$.

Legenda: CR-1 (Saccharomyces bayanus); IZ-987; PE-2 (S. cerevisiae); e IZ259 (S. cerevisiae). 

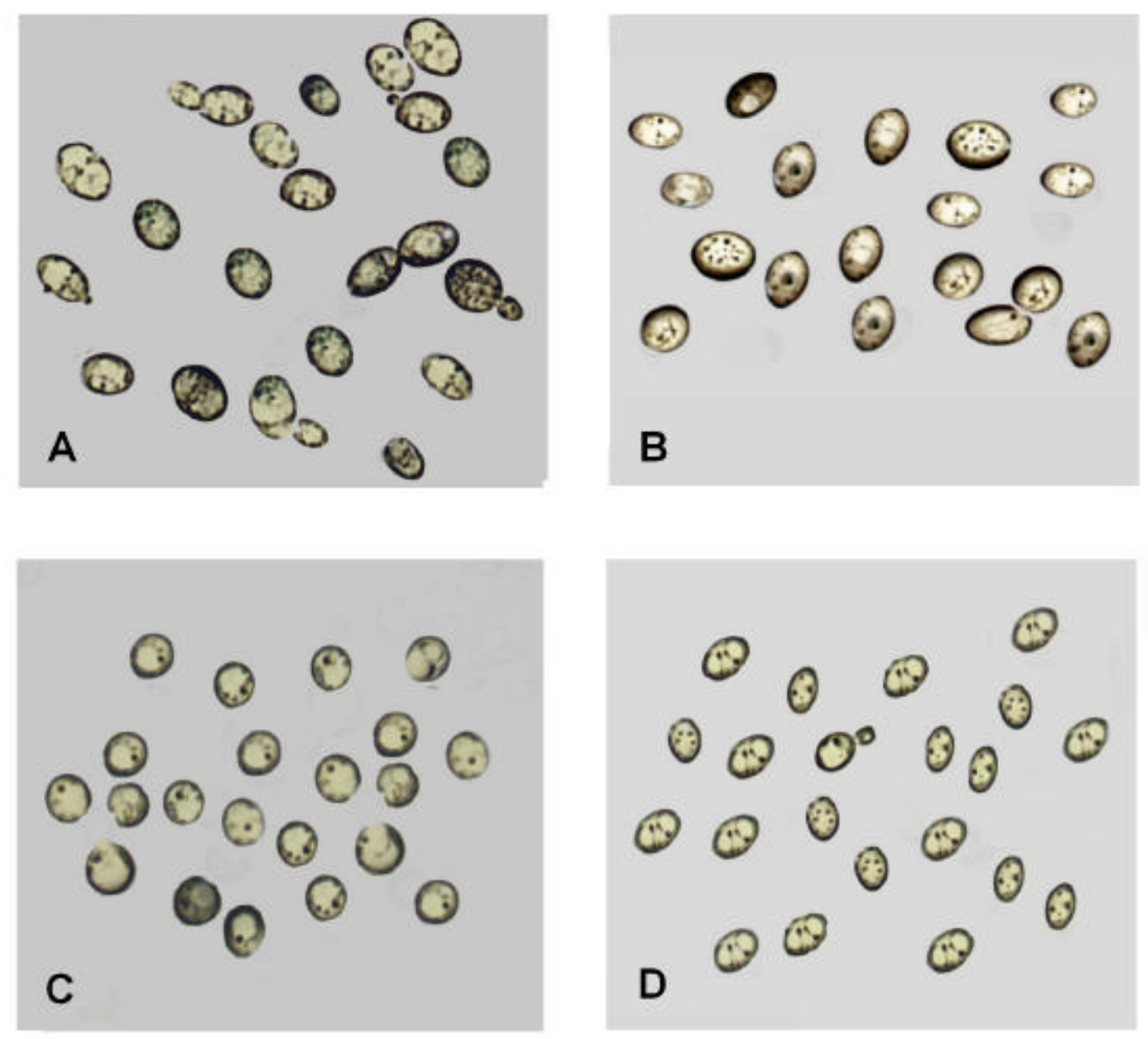

Figura 3 - Características micromorfológicas das linhagens apresentando a forma da célula em meio GYP líquido, incubadas a $30^{\circ} \mathrm{C}$.

Legenda: A) CR-1 (Saccharomyces bayanus); B) IZ-987; C) PE-2 cerevisiae); e D) IZ-259 (S. cerevisiae). Microscopia em imersão, aumento 1000x. 

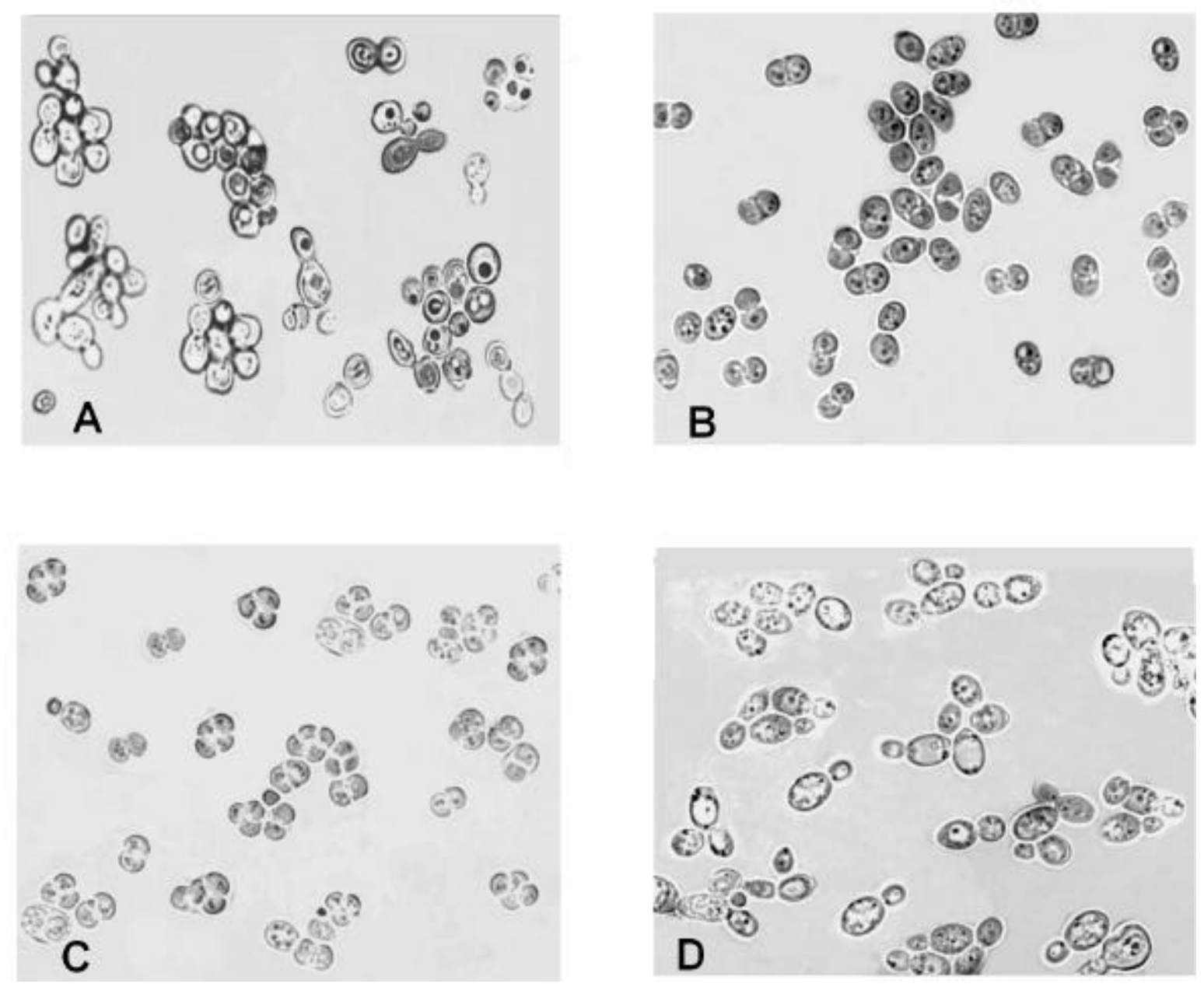

Figura 4 - Esporulação das células após 7 dias de incubação em meio Acetato ágar, a $30^{\circ} \mathrm{C}$.

Legenda: A) IZ-987; B) CR-1 (Saccharomyces bayanus); C) PE-2 (S.cerevisiae); e D) IZ-259 (S. cerevisiae). 
As características morfológicas das linhagens tomadas como padrões dentro do gênero Saccharomyces apresentaram colônias de coloração branca, brilhante com margem inteira, textura butirosa com elevação maminolada e superfície lisa, ausência de pseudomicélio e micélio verdadeiro com exceção da linhagem IZ-259 que apresentou formação de pseudomicélio em meio Corn Mealágar

Com relação ao crescimento a $37^{\circ} \mathrm{C}$ as linhagens PE-2 e CR-1 se desenvolveram de forma satisfatória no meio GYP ágar enquanto que nas linhagens IZ-259 e IZ-987, o crescimento foi lento. A linhagem IZ-987 foi a única a apresentar formação de película em meio líquido.

Microscopicamente todas as linhagens padrões apresentaram células ovais com reprodução assexuada por brotamento multipolar. As linhagens PE-2 e CR-1 apresentaram ascósporos esféricos em número de 2 a 4 ascósporos por asco de tamanho grande; na linhagem IZ-259 também não foi observado a formação de ascósporos (Tabela 2).

\subsubsection{Testes Bioquímicos}

As tabelas 3, 4, e 5, mostram a capacidade fermentativa das linhagens, verificado em tubos de ensaio com tubos de Durham invertidos, e foi observado a formação de gás. Em todas as linhagens foi verificada a fermentação positiva das fontes de sacarose, glicose e maltose e apresentaram resultado negativo quanto a assimilação da lactose, celobiose e melibiose. A linhagem IZ-987 apresentou resultados de fermentação negativos quanto a galactose e a rafinose, enquanto os padrões apresentaram resultados positivos, com exceção da linhagem CR-1 que foi negativo para a galactose.

No que se refere a assimilação (Tabela 4), a linhagem IZ-987 apresentou resultado positivo quanto a eritritol, celobiose e manitol, enquanto os padrões apresentaram resultados negativos. 
Tabela 2. Características morfológicas e sexuais das linhagens de leveduras.

\begin{tabular}{|c|c|c|c|c|c|}
\hline & \multicolumn{4}{|c|}{ Linhagens } \\
\hline & & Z-987 & PE-2 & Z-259 & CR-1 \\
\hline Colônia & $\begin{array}{l}\text { Coloração } \\
\text { Margem } \\
\text { Elevação } \\
\text { Superfície } \\
\text { Brilho } \\
\text { Textura }\end{array}$ & $\begin{array}{c}\text { creme } \\
\text { ondulada } \\
\text { maminolada } \\
\text { estriada } \\
\text { opaca } \\
\text { butirosa }\end{array}$ & $\begin{array}{c}\text { branca } \\
\text { inteira } \\
\text { maminolada } \\
\text { lisa } \\
\text { brilhante } \\
\text { butirosa }\end{array}$ & $\begin{array}{c}\text { branca } \\
\text { inteira } \\
\text { maminolada } \\
\text { lisa } \\
\text { brilhante } \\
\text { butirosa }\end{array}$ & $\begin{array}{c}\text { branca } \\
\text { inteira } \\
\text { maminolada } \\
\text { lisa } \\
\text { brilhante } \\
\text { butirosa }\end{array}$ \\
\hline \multicolumn{2}{|c|}{ Forma de célula } & circular & oval & oval & oval \\
\hline \multicolumn{2}{|c|}{ Tipo de reprodução vegetativa } & $\begin{array}{l}\text { brotamento } \\
\text { multipolar }\end{array}$ & $\begin{array}{l}\text { brotamento } \\
\text { multipolar }\end{array}$ & $\begin{array}{l}\text { brotamento } \\
\text { multipolar }\end{array}$ & $\begin{array}{l}\text { brotamento } \\
\text { multipolar }\end{array}$ \\
\hline \multicolumn{2}{|c|}{ Formação de Pseudomicélio } & negativo & negativo & positivo & negativo \\
\hline \multicolumn{2}{|c|}{ Micélio verdadeiro } & ausente & ausente & ausente & ausente \\
\hline \multicolumn{2}{|c|}{ Número de ascósporos } & ausente & 2 a 4 & ausente & 2 a 4 \\
\hline \multicolumn{2}{|c|}{ Tamanho de ascósporos } & ausente & grandes & ausente & grandes \\
\hline \multicolumn{2}{|c|}{ Forma de ascósporos } & ausente & esféricos & ausente & esféricos \\
\hline \multicolumn{2}{|c|}{ Formação de película em meio líquido } & positivo & negativo & negativo & negativo \\
\hline \multicolumn{2}{|c|}{ Desenvolvimento a $37^{\circ} \mathrm{C}$} & lento & positivo & lento & positivo \\
\hline
\end{tabular}


Tabela 3. Características de fermentação das linhagens IZ-987, PE-2, IZ-259 e CR-1.

\begin{tabular}{|c|c|c|c|c|c|c|c|c|}
\hline \multirow[b]{2}{*}{ Linhagens } & \multicolumn{8}{|c|}{ Fermentação } \\
\hline & Sac. & Gal. & Glic. & Lact. & Raf. & Malt. & Cel. & Mel. \\
\hline Z-987 & + & - & + & - & - & + & - & - \\
\hline PE-2 & + & + & + & - & + & + & - & - \\
\hline Z-259 & + & + & + & - & + & + & - & - \\
\hline CR-1 & + & - & + & - & + & + & - & - \\
\hline
\end{tabular}

Tabela 4. Características de assimilação das linhagens IZ-987, PE-2, IZ-259 e CR-1.

\begin{tabular}{|c|c|c|c|c|c|c|c|c|c|c|c|c|c|}
\hline \multirow[b]{2}{*}{ Linhagens } & \multicolumn{13}{|c|}{ Assimilação } \\
\hline & Sac. & Gal. & Glic. & Lact. & Raf. & Malt. & Erit. & Rib. & Cel. & Man. & Mel. & Ino. & Xil. \\
\hline Z-987 & + & + & + & - & + & + & + & - & + & + & - & - & - \\
\hline PE-2 & + & + & + & - & + & + & - & - & - & - & - & - & - \\
\hline Z-259 & + & + & + & - & + & + & - & - & - & - & - & - & - \\
\hline CR-1 & + & + & + & - & + & + & - & - & - & - & - & - & - \\
\hline
\end{tabular}

Tabela 5. Características bioquímicas das linhagens IZ-987, PE-2, IZ-259 e CR-1.

\begin{tabular}{lccccc}
\hline & Amido & $\mathrm{KNO}_{3}$ & $50 \%$ & $10 \%$ & Produção de \\
Linhagens & & & glicose & $\mathrm{NaCl}$ & Ácido $\left(\mathrm{CaCO}_{3}\right)$ \\
\hline Z-987 & - & - & + & + & $\mathrm{w}$ \\
$\mathrm{PE}-2$ & - & - & + & - & $\mathrm{w}$ \\
$\mathrm{Z}-259$ & - & - & + & + & $\mathrm{w}$ \\
$\mathrm{CR}-1$ & - & - & + & - & $\mathrm{w}$ \\
\hline
\end{tabular}

Legenda: Sac: Sacarose; Gal: Galactose; Glic: Glicose; Lact: Lactose; Raf: Rafinose; Malt: Maltose; Cel: Celobiose; Mel: Melibiose; Erit: Eritritol; Rib: Ribitol; Man: Manitol; Ino: Inositol; Xil: Xilose; Etil: Etilamina; Lis: Lisina; +: Positivo; -: Negativo; w: Fraco. 
Os resultados dos testes de osmotolerância apresentados por todas as linhagens em estudo foi positivo, no meio contendo $50 \%$ de glicose e no meio contendo $10 \%$ de $\mathrm{NaCL}$, as linhagens PE-2 e CR-1 apresentaram resultados negativos e a característica de produção de ácido a partir da glicose em meio $\mathrm{CaCO}_{3}$, todas as linhagens apresentaram produção de ácido de forma fraca, considerado como resultado positivo (Tabela 5).

Os resultados dos testes de assimilação de compostos de nitrogênio demonstraram que todas das linhagens em estudo não assimilaram nitrato de potássio, nitrito de sódio, etilamina e lisina. De igual forma todas as linhagens não apresentaram síntese de compostos semelhantes ao amido (Tabela 6).

Tabela 6. Assimilação das linhagens dos compostos de nitrogênio.

\begin{tabular}{lcccc}
\hline Linhagem & $\begin{array}{c}\text { Nitrato de } \\
\text { potássio }\end{array}$ & $\begin{array}{c}\text { Nitrito de } \\
\text { sódio }\end{array}$ & Lisina & Etilamina \\
\hline Z-987 & - & - & - & - \\
PE-2 & - & - & - & - \\
Z-259 & - & - & - & - \\
CR-1 & - & - & - & - \\
\hline
\end{tabular}

(-): Negativo

\subsection{Técnicas Moleculares}

\subsubsection{Polimorfismo de DNA Amplificado ao Acaso - RAPD}

Com o objetivo de comparar geneticamente a linhagem IZ-987 com as linhagens tomadas como padrões, foi estudada a variabilidade por meio da 
reação de RAPD, onde foi isolado o DNA das linhagens. Foram selecionados dois primers por permitirem a amplificação do DNA e a geração de polimorfismo entre as linhagens.

As reações de RAPD foram realizadas como descrito no item 3.6.2 e com a utilização dos primers (OPAX-17, OPB-11) foi obtido um padrão de amplificação de fragmentos de DNA para as linhagens como demonstrado na Figura 5. Os dois primers geraram 21 bandas polimórficas sendo que a análise da amplificação desses dois primers permitiu a construção de uma matriz de similaridade e posterior elaboração de um dendrograma de similaridade genética entre a linhagem IZ-987 e as linhagens padrões PE-2, IZ-259 e CR-1 (Figura 6).

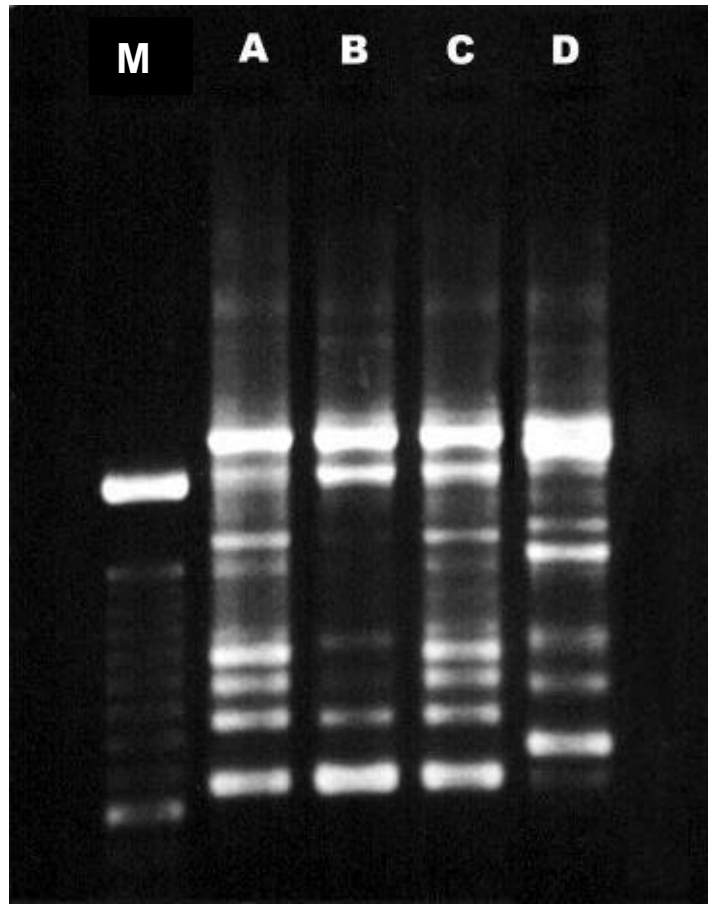

$\mathbf{1}$

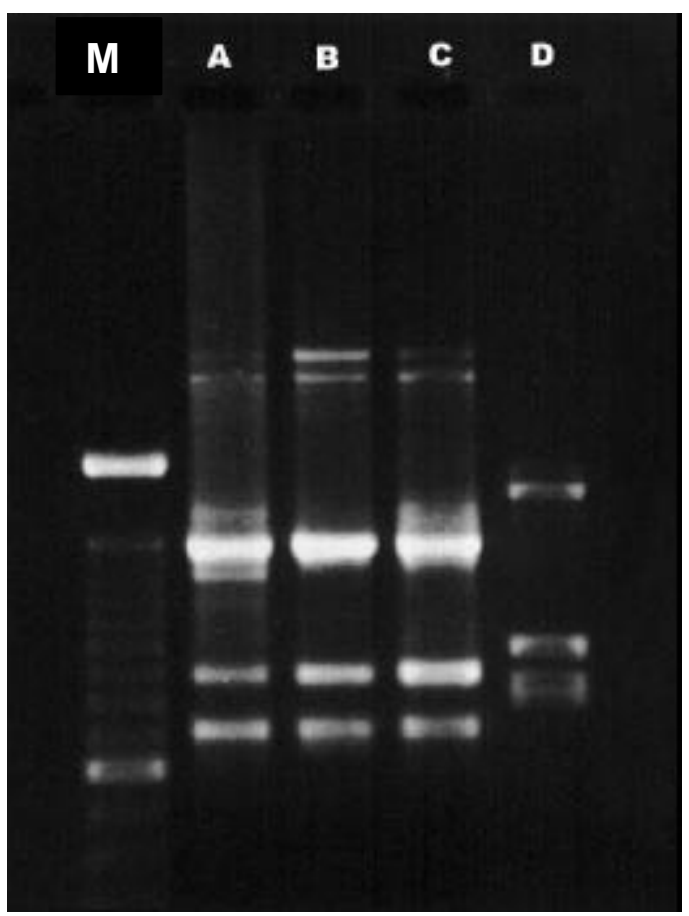

2

Figura 5 - Perfil de RAPD das diferentes linhagens com os primers: OPAX-17 e 2) OPB-11. 
Legenda: M) marcador de peso molecular 100 pb DNA Ladder (Life Technologies); A) PE-2 (Saccharomyces cerevisiae); B) IZ-259 ( S. cerevisiae); C) CR-1 ( S. bayanus) e D) IZ-987.

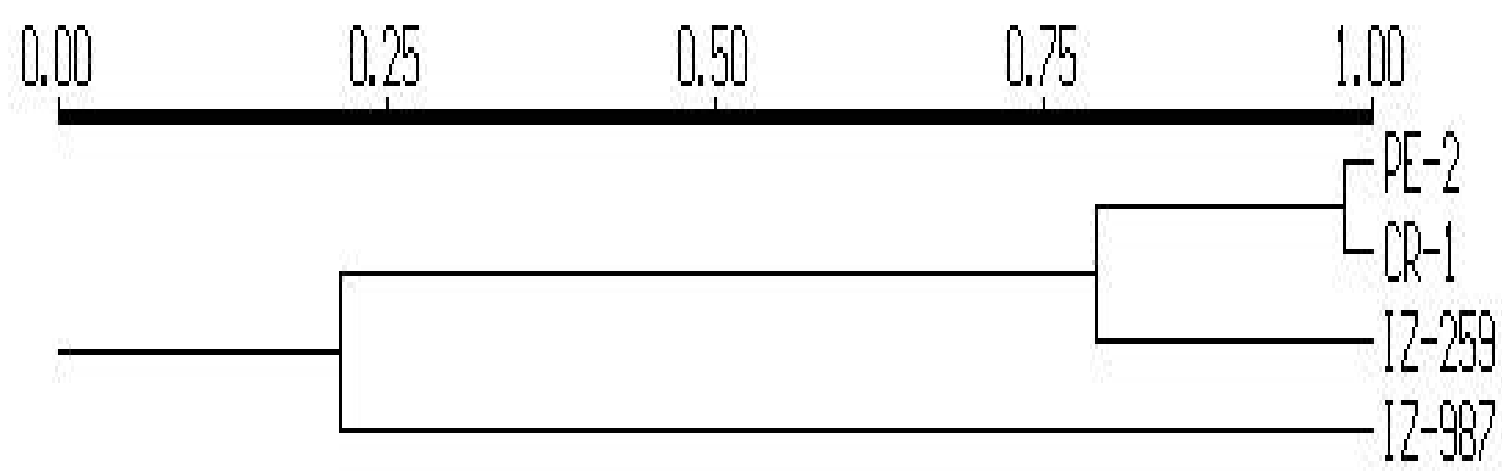

Figura 6 - Dendrograma obtido a partir da matriz de similaridade genética entre as linhagens, a partir de dados obtido pelo método RAPD.

Legenda: PE-2 (Saccharomyces cerevisiae); CR-1 (S. bayanus); IZ-259 cerevisiae); IZ-987.

Com base nos dados na Figura 5 constata-se que as linhagens de comparação apresentaram um padrão de bandas bem definidas, enquanto que a linhagem IZ-987 apresentou um padrão diferenciado.

A reação de RAPD é um método sensível e eficiente na identificação de linhagens muito semelhantes, como as linhagens padrões, as quais apresentam alto coeficiente de similaridade. Partindo destas observações pode-se sugerir que o baixo coeficiente de similaridade observado entre os padrões e a linhagem Z-987 aponta para uma grande distância taxonômica entre eles, reforçando a hipótese de a linhagem IZ-987 não pertencer ao gênero Saccharomyces (Martins et al., 1998). 


\subsection{Separação de DNA Cromossômico das Leveduras}

Com a utilização de métodos genéticos, foi proposto verificar a relação taxonômica da linhagem IZ-987 com as linhagens tomadas como padrões de gênero Saccharomyces realizada através da cariotipagem eletroforética destas leveduras.

A eletroforese em campo pulsado previamente desenvolvido em Saccharomyces cerevisiae vem sendo aprimorada, permitindo a obtenção de bandas cromossômicas de vários microrganismos (Basso et al., 1992; Allegrucci et al., 1993).

A separação das bandas individualizadas muito intensas não representam necessariamente um cromossomo uma vez que dois ou mais cromossomos podem ter igual peso molecular ou peso molecular próximos e podem estar contidos em uma mesma banda. Dessa forma, no presente trabalho se assume que cada banda corresponda a apenas um cromossomo.

Na Figura 7 e Tabela 7 observam-se que os padrões eletroforéticos das linhagens tomadas como padrões do gênero Saccharomyces são muito diferentes da linhagem IZ-987 que mostrou a resolução de somente 3 bandas cromossômicas enquanto a linhagem CR-1 apresentou 13 bandas cromossômicas, IZ-259 apresentou 16 bandas e a linhagem PE-2 apresentou 12 bandas. Por outro lado, pode-se observar que os padrões de resolução das bandas cromossômicas das linhagens padrões de Saccharomyces, utilizando a separação de cromossomos pelo método TAFE, encontra-se diferenças nos padrões de bandeamento quanto ao número de bandas obtidas.

Os padrões de resolução das bandas cromossômicas indicam possivelmente que as diferenças nos padrões de bandas obtidas pela separação do DNA cromossômico das linhagens padrões do gênero Saccharomyces e da linhagem IZ-987 sejam oriundas de uma grande distância taxonômica entre estas linhagens, pertencendo a linhagem IZ-987 a outro gênero. 


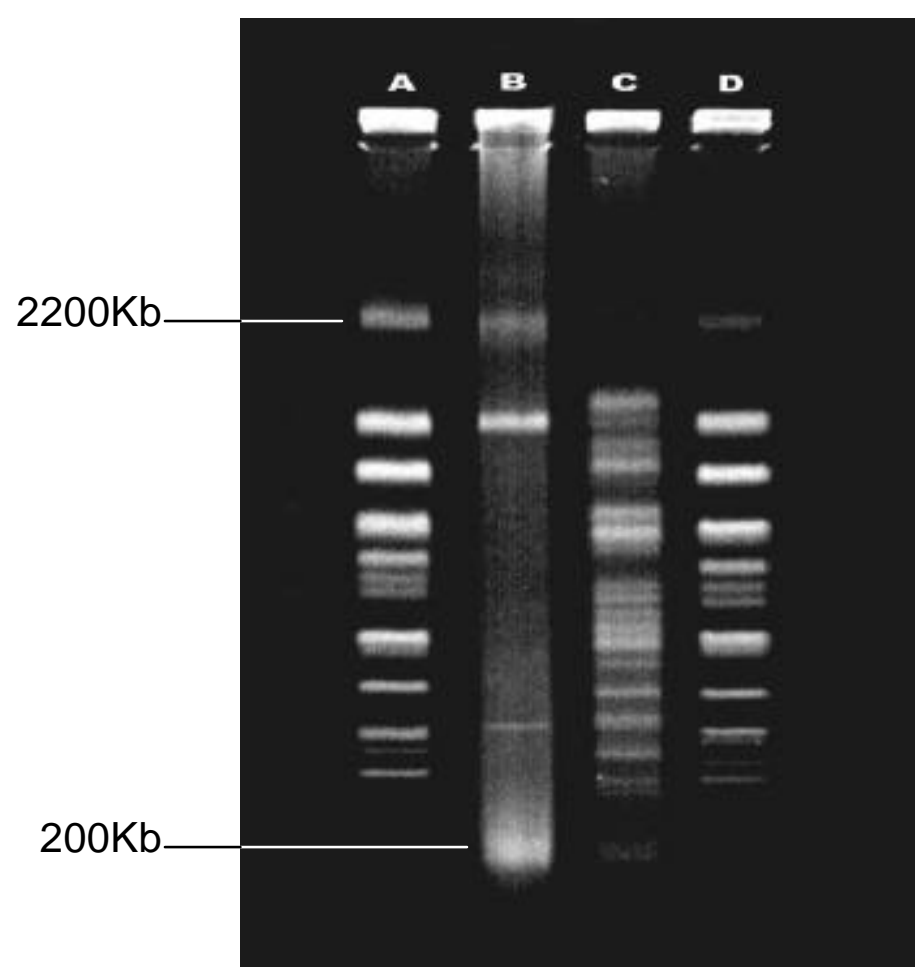

Figura 7 - Eletroforese em campo pulsado.

Legenda: A) CR-1 (Saccharomyces bayanus); B) IZ-987; C) IZ-259

$(S$. cerevisiae); e D) PE-2 (S. cerevisiae). 
Tabela 7. Organização das bandas de cromossomos das leveduras de acordo com sua migração no gel.

\begin{tabular}{|c|c|c|c|c|}
\hline Bandas & CR-1 & Z-987 & Z-259 & PE-2 \\
\hline 1 & $x X$ & $x X$ & & $x x$ \\
\hline 2 & & & $x x$ & \\
\hline 3 & $x x$ & $x x$ & $x x$ & $x x$ \\
\hline 4 & & & $x x$ & \\
\hline 5 & $x x$ & & $x x$ & $x x$ \\
\hline 6 & & & $x x$ & \\
\hline 7 & $x x$ & & $x x$ & $x x$ \\
\hline 8 & $x x$ & & $x x$ & $x x$ \\
\hline 9 & $x x$ & & $x x$ & $x x$ \\
\hline 10 & $x x$ & & $x x$ & $x x$ \\
\hline 11 & & & $x x$ & \\
\hline 12 & $x x$ & & $x x$ & $x x$ \\
\hline 13 & $x x$ & & $x x$ & $x x$ \\
\hline 14 & $x x$ & & & $x x$ \\
\hline 15 & & & $x x$ & \\
\hline 16 & $x x$ & $x x$ & & $x x$ \\
\hline 17 & $x x$ & & $x x$ & \\
\hline 18 & $x x$ & & $x x$ & $x x$ \\
\hline 19 & & & $x x$ & \\
\hline
\end{tabular}




\subsection{Sequenciamento e Identificação da Linhagem IZ-987}

A amplificação do produto de PCR foi feita de acordo com item 3.6.4. Foi observada uma banda de aproximadamente 620 pb, que após purificação (Figura 8) foi clonada no plásmidio pGEM-T (Promega). Dessa forma, após a confirmação da presença do inserto no plasmídio, este foi enviado para sequenciamento, a qual após processamento foi analisado na base de dados BLAST (http://www.ncbi.nlm.nih.gov/BLAST). A similaridade entre a seqüência da linhagem IZ-987 foi estudado com aquelas seqüências depositadas no Gene Bank. Esta análise mostrou que a seqüência obtida da linhagem IZ-987

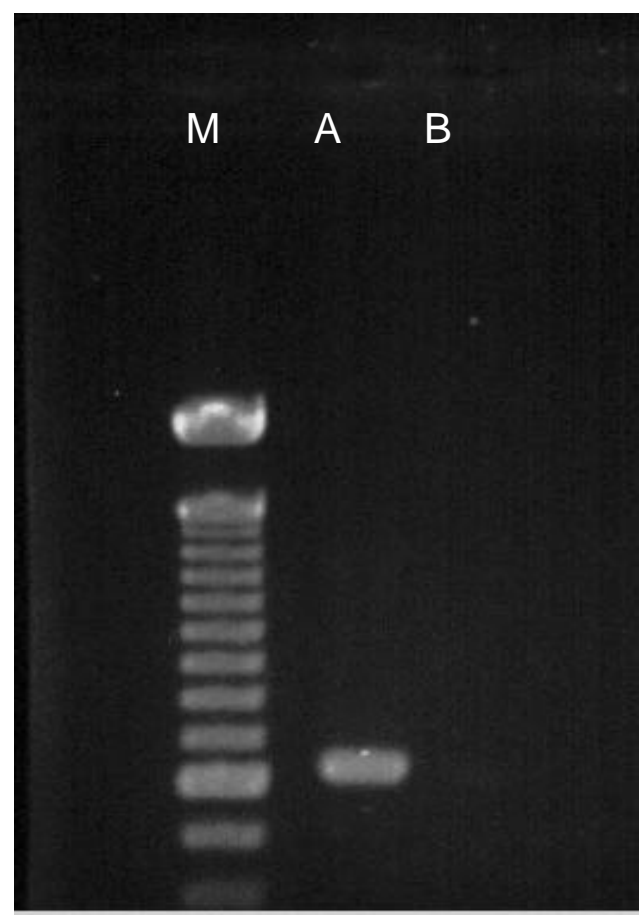

apresentou maior a 96\% de similaridade com Pichia anomala (Tabela 8). 
Figura 8 - Gel de agarose $(1,2 \%)$ mostrando fragmento de aproximadamente 620 pb purificado a partir da reação de PCR com os primers ITS1 e ITS4 do gene que codifica para a subunidade $18 \mathrm{~S}$ do RNA ribossômico.

Legenda: M) marcador de DNA $\lambda$ clivado com Hind III (Gibco BRL - Life Technologies); A) linhagem IZ-987; e B) branco.

Tabela 8. Análise da linhagem IZ-987 pela seqüência do 18S rDNA e similaridade da seqüência com dados obtidos de espécies já seqüenciadas e depositadas no Gene Bank.

\begin{tabular}{cccc}
\hline Linhagem & Tamanho & Espécie & Similaridade \\
\hline Z-987 $600 \mathrm{pb}$ & $-620 \mathrm{pb}$ & Pichia anomala & $>96 \%$ \\
\hline
\end{tabular}




\section{CONCLUSÕES}

Os resultados obtidos permitiram concluir que:

- Os métodos adotados para a identificação e caracterização da linhagem IZ987 mostraram-se eficazes e complementares no estudo em pauta.

- Os dados morfológicos, indicaram que a linhagem IZ-987 não apresenta similaridade com as linhagens padrões PE-2, IZ-259, e CR-1.

- Os testes fisiológicos e bioquímicos da linhagem IZ-987 e das linhagens padrões apresentaram maior similaridade entre si, não sendo suficiente, no entanto, no nível empregado, para identificar com segurança o gênero e a espécie.

- As análises de diversidade genética por marcadores de RAPD e cariotipagem demonstraram que existe um distanciamento elevado entre a linhagem IZ-987 e os padrões de Saccharomyces cerevisiae.

- A análise da seqüência das regiões ITS1 e ITS2 (incluindo a subunidade 5,8S do RNA ribossomal) da linhagem IZ-987, mostrou similaridade (>96\%) com a espécie Pichia anomala. 
ANEXO 


\title{
Seqüência Das Regiões Ribossomais da Levedura IZ-987 (Seqüência Parcial do 18S rDNA, ITS1, Seqüência completa do 5,8S rDNA, ITS2 e Seqüência parcial do $28 S$ rDNA)
}

\author{
Primers: $\quad$ ITS1 (TCC GTA GGT GAA CCT GCG G) \\ ITS4 (TCC TCC GCT TAT TGA TAT GC)
}

Tamanho: $620 \mathrm{pb}$

TCCGTAGgTgAACCTGCGgAAGGATCATTATAGTATTCTATTGCCAGCGCTTAATTGCG CGGCGATAAACCTTACACACATTGTCTAGTTTTTTTGAACTTTGCTTTGGGTGGTGAGC CTGGCTTACTGCCCAAAGGTCTAAACACATTTTTTTAATGTTAAAACCTTTAACCAAT

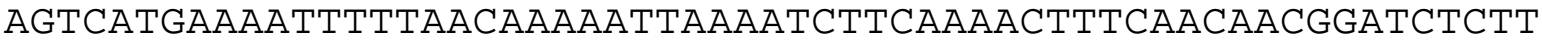
GGTTCTCGCAACGATGAAGAACGCAGCGAAATGCGATACGTATTGTGAATTGCAGATTT TCGTGAATCATCGAATCTTTGAACGCACATTGCACCCTCTGGTATTCCAGAGGGTATGC CTGTTTGAGCGTCATTTCTCTCTCAAACCTTCGGGTTTGGTATTGAGTGATACTCTGTC AAGGGTTAACTTGAAATAT TGACTTAGCAAGAGTGTACTAATAAGCAGTCTTTCTGAAA TAATGTATTAGGTTCTTCCAACTCGTTATATCAGCTAGGCAGGTTTAGAAGTATTTTAG GCTCGGCTTAACAACAATAAACTAAAAGT T TGACCTCAAATCAGGTAAGGACTACCCGC TGAACTTAAGCATATCAATAAGCGGAGGGA

BLAST $_{\mathrm{N}}$ última data avaliada 24. 06.02

1.- Pichia anomala

$585 / 605$

$96 \%$

2.- Pichia anomala

$546 / 561$

$97 \%$ 


\section{REFERÊNCIAS BIBLIOGRÁFICAS}

ADAMS, J.; PUSKAS-ROZZA, S.; SIMLAR,J. et al. Adaptation and major chromosomal changes in populations of Saccharomyces cerevisiae. Current Genetics, v.22, n.1, p.13-19, 1992.

ALLEGRUCCI, M.; LANFALONI, L.; BIETTA, C. et al. The electrophoretic karyotype of two strains of Candida albicans by transverse alternative field electrophoresis reveals higher number of chromosomes ranging from 1 to $35 \mathrm{Mb}$. Yeast, v.9, n.11, p.1213-1218, 1993.

ARX, J.A.; SCHIPPER, M.A.A. The CBS fungus collection. Advances in Applied Microbiology, v.24, n.1, p.215-236, 1978.

BALEIRAS-COUTO, M.M.; VOGELS, J.T.W.E.; HOFSTRA, H. et al. Random amplified polymorphic DNA and restriction enzyme analysis of PCR amplified rDNA in taxonomy. Journal of Applied Bacteriology, v.79, n.5, p.525-535, 1995.

BARNETT, J.A. The taxonomy of the genus Saccharomyces Meyen ex Reess: a short review for non-taxonomists. Yeast, v.8, n.1, p.1-23, 1992.

BARNETT, J.A.; PAYNE, R.W.; YARROW, D. Yeasts: characteristics and identifications. Cambridge: Cambridge University Press, 1983. 811p. 
BARNETT, J.A.; PAYNE, R.W.; YARROW, D. Yeasts: characteristics and identifications. Cambridge: Cambridge University Press, 1990. 1002p.

BASSO, L.C.; AMORIM, H.V.; OLIVEIRA, A.J. et al. Identificação de leveduras pela técnica da eletroforese do DNA cromossomico (cariotipagem). Piracicaba: USP/ESALQ, Depto. Química / FERMENTEC, 1992. p.101-110 (Relatório Anual de Pesquisas em Fermentação Alcoólica, 12)

BASSO, L.C.; OLIVEIRA, A.J.; ORELLI, V.F.D.M. et al. Dominância das leveduras contaminantes sobre as linhagens industriais avaliada pela técnica da cariotipagem. In: CONGRESSO NACIONAL DA STAB, 5., Águas de São Pedro,1993. Anais. Piracicaba: STAB, 1993. p.245-250.

BERED, F.; BARBOSA NETO, J.F.; CARVALHO, F.I.F. Marcadores moleculares e sua aplicação no melhoramento genético de plantas. Ciência Rural, v.27, n.3, p.513-520, 1997.

BERNHARDT, E. Time saving in the preparation of corn meal ágar and in the identification of yeast-like fungi. Mycologia, v.38, p.228-229, 1946.

BLODIN, B.; VÉZINHET,F. Identification de souches de levure oenologiques par leur caryotypes obtenus en electrophorese em champ pulse. Revue Française d' Oenologia, v.28, p.7-11, 1988.

CARLE, G.F.; OLSON, M.V. Separation of chromosomal DNA molecules from yeast by orthogonal-alternation gel electrophoresis. Nucleic Acids Research, v.12, n.14, p.5647-5664, 1984.

CARLE, G.F.; FRANK, M.; OLSON, M.V. Electrophoretic separations of large DNA molecules by periodic inversion of the electric field. Science, v.232, n.1, p.65-68, 1986. 
CARMO DE SOUZA, L. Distribution of yeasts in natura. In: ROSE, A.H.; HARRISON, J.S. (Ed.). The yeasts: biology of the yeasts. London: Academic Press, 1969. v.1, p.9-106.

CASTRO, M.S. Usinas de açúcar e álcool: estudo das leveduras e dos fatores que afetam a fermentação. Campinas: Fundação Tropical de Pesquisas e Tecnologia "André Tosello", 1995. 126p.

CASTRO, T.M.G. Eletroforese em gel de acrilamida. Curso teórico-prático de eletroforese, Nova Odessa, 1988. v.4, p.43-45.

CECCATO-ANTONINI, S.R.; SILVA, D.F. Eficiência de meios diferenciais no isolamento de cepas de leveduras de processos industriais de fermentação alcoólica. STAB: Açúcar, Álcool e Subprodutos, v.18, n.5, p.40-46, 2000.

CHU, E.; VOLLRATH, D.; DAVIS, R.W. Separation of large DNA molecules by contour-clamped homogeneous eletric fields. Science, v.234, p.1582-1585, 1986.

DEGRÉ, R.; THOMAS, D.Y.; ASH, J. et al. Wine yeasts strain identification. American Journal Enology and Viticulture, v.40, n.4, p.309-314, 1989.

FERREIRA, M.E.; GRATTAPAGLIA, D. Introdução ao uso de marcadores moleculares em análises genéticas. 3.ed. Brasília: EMBRAPA, CENARGEN, 1998. 220p.

FUNGARO, M.H.; VIEIRA, M.L.C. Aplicações da PCR em ecologia molecular. In: MELO, J.S.; AZEVEDO, J.L. (Ed.). Ecologia microbiana. Jaguariúna: EMBRAPA, CNPMA, 1998. cap.8, p.205-227. 
GARDINER, K.; LAAS, W.; PATTERSON, D. Fractionation of large mammalian: DNA restriction fragments using pulsed-field gradient gel electrophoresis. Somatic Cell and Molecular Genetics, v.12, n.2, p.185-195, 1986.

GARDINER, K.; PATTERSON, D. Transverse alternating electrophoresis. Nature, v.331, p.371-372, 1988.

HOOG, G.S. de. Significanse of fungal evolution for the understanding of their pathogenicity illustrated with agents of phacohyphomycosis. Mycosis, v.40, p.5-8, 1997. Supplement, 2.

HOOG, G.S. de; BOWMAN, B.; GRASER, Y. et al. Molecular phygeny and taxonomy of medically important: Fungi. Medical Mycology, v.36, p.52-56, 1998. Supplement, 1.

JONGE, P. de.; JONGH, F.C. de.; MEIJERS, H. et al. Orthogonal-field alternation gel electrophoresis banding patterns of DNA from yeast. Yeast, v.2, n.3, p.193-204, 1986.

KERSTERS, K.; DE LEY, J. Identification and grouping of bacteria by numerical analysis of their eletrophoretic protein patterns. Journal of General Microbiology, v.87, n.1, p.333-342, 1975.

KOCKOVÁ-KRATOCHVÍLOVÁ, A.; SLÁVIKOVÁ, E.; SIN, J.D. Yeasts and yeast-like organisms from North Korea. The Journal of General and Applied Microbiology, v.35, n.2, p.135-149, 1989.

KREGER-VAN RIJ, N.J.W. Classification of yeasts. In: ROSE, A.H.; HARRISON, J.S. (Ed.). The yeasts. London: Academic Press, 1987. v.1, p.5-61. 
KREGER-VAN RIJ, N.J.W. General classification of the yeasts. In: KREGERVAN RIJ, N.J.W. The yeasts: a taxonomy study. Amsterdam: Elsevier Science, 1984a. p.1-44.

KREGER-VAN RIJ, N.J.W. Genetic differentiation in yeasts. In: SKINNER, F.A.; PASSMORE, S.M.; DAVENPORT, R.R. (Ed.). Biology and activities of yeasts. London: Academic Press, 1980. p.29-52.

KREGER-VAN RIJ, N.J.W. The yeasts: a taxonomy study. Amsterdam: Elsevier Science, 1984b. 1082p.

KURTZMAN, C.P. Identifications and taxonomy. In: KIRSOP, B.E.; KURTZMAN, C.P. (Ed.). Living resources for biotechnology: yeasts. New York: Cambridge, 1988. p.99-140.

KURTZMAN, C.P.; PHAFF, H.J. Molecular taxonomy. In: ROSE, A.H.; HARRISON, J.S. (Eds.). The yeasts: biology of the yeasts. London: Academic Press, 1969. v.1, p.63-64.

LALANDE, M.; NOOLANDI, J.; TURMEL, C. et al. Pulsed-field electrophoresis: applications of a puter model to the separation of large DNA molecules. Proceedings National Academy Science, v.84, n.1, p.3011-3015, 1987.

LINK, A.J.; OLSON, M.V. Physical map of the Saccharomyces cerevisiae genome at 110-Kilobase resolution. Genetics, v.127, n.4, p.681-698, 1991.

LOBRICH, M.; IKPEMES, S.; KIEPER, J. Analysis of the inversion effect im pulsed field gel electrophoresis by a two-dimensional contour clamped homogeneous electric field system. Analytical Biochemistry, v.208, n.1, p.65-73, 1993. 
LODDER, J. The yeasts: a taxonomy study. Amsterdam: North-Holland Publishing Company, 1971. 1385p.

MARTINS, C.V.B.; HORII, J.; PIZZIRANI-KLEINER, A.A. Fusão de protoplastos de Saccharomyces cerevisiae avaliada por floculação e produção de $\mathrm{H}_{2} \mathrm{~S}$. Scientia Agricola, v.55, n.1, p.64-72, jan./abr. 1998.

MASNEUF, I.; AIGLE, M.; DUBORDIEU, D. Development of a polymerase chain-restriction reaction fragment lenght polymorphism method for Saccharomyces cerevisiae and Saccharomyces bayanus identification in enology. FEMS Microbiology Letters, v.138, n.2-3, p.239-244, 1996.

McCLUSKEY, K.; RUSSEL, B.W.; MILLS, D. Electrophoretic karyotyping without the need for generating protoplasts. Current Genetics, v.18, p.385386, 1990.

MEYER, S.A. DNA reassociation and protein electrophoresis useful tools to evaluated yeasts. In: KURTZMAN, C.P.; MEYER, S.A.; SCHENBERG, A.C.G. et al. Leveduras para biotecnologia: Campinas: Fundação Tropical de Pesquisas e Tecnologia "André Tosello", 1991, 49p. Curso.

MIAO, V.P.M.; VANETTEN, H.D. Preparing chromosomes from protoplast of filamentous fungus for pulsed-field gel electrophoresis. Biotechniques, v.8, n.1, p.393, 1990.

MILLS, D.; McCLUSKEY, K. Electrophoretic karyotypes of fungi. The new cytology. Molecular Plant: Microbe Interactions, v.3, n.6, p.351-357, 1990.

MOLNÁR, O.; PRILLINGER, H.; LOPANDIC, K. et al. Analysis of coenzyme Q systems, monosaccharide patterns of purified cell walls, and RAPD-PCR patterns in the genus Kluyveromyces. Antoine van Leeuwenhoek, v.70, n.1, p.67-78, 1996. 
MULLIS, K.; FALOONA, F. Specific synthesis of DNA in vitro a polymerasecatalyzed chain reaction. Methods in Enzymology, v.155, p.335, 1987.

NAKASE, T.; KOMAGATA, K. Significance of DNA base composition in the classification of yeasts genus Saccharomyces. The Journal of General and Applied Microbiology, v.17, p.227-238, 1971.

NAUMOV, G.L.; NAUMOVA, E.S.; MANTTO, R.A. et al. Genetic homology between Saccharomyces cerevisiae and its sibling species S.paradoxus and S. bayanus: electrophoretic karyotypes. Yeast, v.8, n.8, p.599-612, 1992.

PHAFF, H.J. Isolation of yeasts from natural sources. In: LABEDA, D.P. (Ed.). Isolation of biotechnological organisms from nature. New York: McGraw-Hill, 1990. p.53-79.

PHAFF, H.J.; MILLER, M.W.; MRAK, E.M. The life of the yeasts. Cambridge: Harvard University Press, 1978. 341p.

PHAFF, H.J.; STARMER, W.T. Yeasts associated woth plants, insects and soils. In: ROSE, A.H.; HARRISON, J.S. (Ed.). The yeasts: biology of the yeasts. London: Academic Press, 1969. v.1, p.123-180.

PIZZIRANI-KLEINER, A.A.; AZEVEDO, J.L. Manual de técnicas eletroforéticas para separação de cromossomo de microrganismos. Piracicaba: FEALQ, 1989. 31p. (Manual Técnico)

QUESADA, M.P.; CENIS, J.L. Use of randem amplified polymorphic DNA (RAPD-PCR) in the caracterization of wine yeasts. American Journal of Enology and Viticulture, v.46, n.2, p.204-208, 1995.

RAEDER,U.; BRODA, P. Rapid preparation of DNA from filamentous Fungi. Letters in Applied Microbiology, v.1, n.1, p.17-20, 1985. 
ROMANOS, M.A.; SCORER, C.A.; CLARE, J. Foreign gene expression in yeast: a review. Yeast, v.8, n.6, p.423-488, 1992.

ROSINI, G.; FEDERICI, F.; VAUGHAM, A.E. et al. Sistematics of the species of the yeast genus Saccharomyces associated with the fermentation industry. European. Journal of Applied Microbiology and Biotechnology, v.15, n.3, p.188-193, 1982.

SAMBROOK, J.; FRITSCH, E.F.; MANATIS, T. Molecular cloning: a laboratory manual. New York: Cold Spring Harbor, 1989. v.3.

SCHWARTZ, D.; CANTOR, C.R. Separation of yeast chromossome sized DNAs by pulsed field gradient gel electrophoresis. Cell, v.37, n.1, p.67-75, 1984.

SHEEHAN, C.A.; WEISS, A.S. Brewing yeast identification and chromosome using high resolution CHEF gel electrophoresis. Journal the Institute of Brewing, v.97, n.3, p.163-167, 1991.

SORRELLS, M.E.; NACHIT, M.M.; BARBOSA NETO, J.F. et al. Relationships among 81 Durum genotypes based on RFLPs gliadins, parentage and quality traits. In: SEMINAR ON DURUM WHEAT QUALTY IN THE MEDITERRANEAN REGION, Zaragoza, 1993. Anais. Zaragoza: CIHEAM / ICARDA/CIMMYT, 1993. p.20.

STEWART, G.; FURS, A.; AVDALOVIC, N. Transverse alternating field electrophoresis (TAFE). Biotechniques, v.6, p.68-73, 1988.

TAVARES, F.C.A.; ECHEVERRIGARAY, S.; GOMES, L.H. et al. Identificação molecular de leveduras de fermentação. STAB: Açúcar, Álcool e SubProdutos, v.10, n.4, p.34-39, 1992. 
TAYLOR, G.T.; MARSH, A.S. MYGP + cooper, a medium that detects both Saccharomyces and non-Saccharomyces wild yeast in the presence of culture yeast. Journal of the Institute of Brewing, v.90, n.3, p.134-145, 1984.

THORNTON, R.J.; BUNKER, A. Characterization of wine yeasts for genetically modifiable properties. Journal of the Institute of Brewing, v.95, n.3, p.181184, 1989.

TOROK, T.; ROYER, C.; ROCKOHOLD, D.; KING, A.D.J. Eletrophoretic karyotyping of yeasts and southern blotting using whole chromosomes as templates for the probe preparation. The Journal of General and Applied Microbiology, v.38, n.4, p.313-325, 1992.

UIJTHOF, J.M.J.; HOOG, G.S. de; COCK, A.W.A.M. et al. Patogenicity of strains of the black yeast Exophiala (Wangiella) dermatitidis: na evolution based on polymerase chain reaction. Mycoses, v.37, p.235-242, 1994.

VALENTE, P.; GOUVEIA, F.C.; DELEMOS, G.A. et al. PCR amplification of the rDNA internal transcribed spacer region for differentiation of Saccharomyces cultures. FEMS Microbiology Letters, v.137, n.2-3, p.253-256, 1996.

VAUGHAN-MARTINI, A.; MARTINI, A.; CARDINALI, G. Eletrophoretic karyotyping as a taxonomic tool in the genus Saccharomyces. Antoine Van Leeuwenhooek, v.63, n.2, p.145-156, 1993.

VOLLRATH, D.; DAVIS, R.W. Resolution of DNA molecules greater than 5 megabases by contour-clamped homogeneous eletric fields. Nucleic Acids Research, v.15, n.19, p.7865-7876, 1987. 
WALT, J.P. van der.; YARROW, D. Methods for isolation maintenance, classification and identification of yeasts. In: KREGER-VAN RIJ, N.J.W. (Ed.). The yeasts: a taxonomy study. Amsterdam: Elsevier Science, 1984. p.45-104.

WAUGH, R.; POWELL, W. Using markers for crop improvement. Trends in Biotechnology, v.10, p.186-191, 1992.

WELSH, J.; McCLELLAND, M. Fingerprinting genomes using PCR with arbitrary primers. Nucleic Acids Research, v.18, n.24, p.7213-7218, 1990.

WICKERHAM, L.J. A critical evaluation of the nitrogen assimilation test commonly used in the classification of yeasts. Journal of Bacteriology, v.52, n.1, p.293-301, 1946.

WILLIAMS, J.G.K.; KUBELIK, A.R.; LIVAK, K.J. et al. DNA polimorphisms amplified by arbitrary primers are useful as genetics markers. Nucleics Acids Research, v.18, n.22, p.6531-6535, 1990. 